\title{
Conformational Stability of Ibuprofen: Assessed by DFT Calculations and Optical Vibrational Spectroscopy
}

\author{
M.L. VUEBA, ${ }^{1}$ M.E. PINA, ${ }^{1}$ L.A.E. BATISTA DE CARVALHO ${ }^{2}$ \\ ${ }^{1}$ Centro de Estudos Farmacêuticos (CEF), Laboratório de Galénica e Tecnologia Farmacêutica, Faculdade de Farmácia, \\ Universidade de Coimbra, Rua do Norte, 3000-295 Coimbra, Portugal \\ ${ }^{2}$ Unidade I\&D "Química-Física Molecular", Faculdade de Ciências e Tecnologia, Universidade de Coimbra, Rua Larga, \\ 3004-535 Coimbra, Portugal
}

Received 2 November 2006; revised 5 February 2007; accepted 9 March 2007

Published online in Wiley InterScience (www.interscience.wiley.com). DOI 10.1002/jps.21007

\begin{abstract}
A thorough conformational analysis of ibuprofen [2-(4-isobutylphenyl) propionic acid] was carried by out, using density functional theory (DFT) calculations coupled to optical vibrational spectroscopy (both Raman and FTIR). Eight different geometries were found to be energy minima. The relative orientations of the substituent groups in the ibuprofen molecule, which can be considered as a para-substituted phenyl ring, were verified to hardly affect its conformational stability. The internal rotations converting the calculated conformers of ibuprofen were studied and the intramolecular interactions governing the conformational preferences of the molecule were analyzed by quantitative potential energy deconvolution using Fourier type profiles. The harmonic vibrational frequencies and corresponding intensities were calculated for all the conformers obtained, leading to the assignment of the spectra, and evidencing the sole presence of one of the lowest energy conformers in the solid state. Vibrational spectroscopic proof of intermolecular hydrogen bonds between the carboxylic groups of adjacent ibuprofen molecules, leading to the formation of dimers, was also obtained. ( 2007 Wiley-Liss, Inc. and the American Pharmacists Association J Pharm Sci 97:845-859, 2008
\end{abstract}

Keywords: ibuprofen; DFT calculations; Raman spectroscopy; FTIR spectroscopy; conformational analysis; rotational isomerism

\section{INTRODUCTION}

The knowledge of the conformational preferences of some nonsteroidal anti-inflammatory drugs (NSAID's), particularly the substituted $\alpha$-arylpropionic acids, is of the utmost importance for a better understanding of the structure-activity relationships (SAR's) underlying their biological activity, as well as of their mechanism of action,

Correspondence to: L.A.E. Batista de Carvalho (Telephone: +351-239854462; Fax: +351-239826541; E-mail: labc@ci.uc.pt)

Journal of Pharmaceutical Sciences, Vol. 97, 845-859 (2008)

(C) 2007 Wiley-Liss, Inc. and the American Pharmacists Association which can be related to the ability to inhibit prostaglandin synthesis. ${ }^{1-3}$ In fact, several studies are reported which establish the monocarboxylic acid group responsible for the antiinflammatory, analgesic, and antipyretic properties of these compounds. ${ }^{4-6}$ However, different ring substitution is known to give rise to distinct pharmacological properties, probably due to pharmacokinetic and pharmacodynamic variations. Moreover, the conformational behavior of the drug determines the chemical and/ or physical mechanisms (i.e., intermolecular interactions) controlling its release into the body from a particular delivery system, and consequently its bioavailability. 
Different physico-chemical methods have been employed for obtaining structural information on pharmacologically relevant systems, as well as for understanding the interactions between the therapeutically active agent and the excipients and/or carriers. Among these, Raman spectroscopy has lately become more and more used as a fast and nondestructive technique for the study of this kind of compounds, since it allows a direct observation of the sample, without any special preparation procedures that could interfere with its conformational characteristics. ${ }^{7-9}$ Moreover, the information yielded by Raman spectroscopy is complementary to the one gathered by infrared analysis, both methods providing a complete vibrational information on a particular molecule.

Ibuprofen (Fig. 1) (2-(4-isobutylphenyl) propionic acid), the parent compound of the "profen"- type NSAID's, is a weakly acidic ( $\left.\mathrm{p} K_{\mathrm{a}}=4.6\right)$, poorly water-soluble drug (water solubility $\approx 0.05 \mathrm{mg} / \mathrm{mL}$ at $\left.25^{\circ} \mathrm{C}\right),{ }^{10}$ frequently used for the treatment of painful and inflammatory conditions such as rheumatoid arthritis, osteoarthritis, and ankylosing spondylitis. ${ }^{11}$ This compound comprises a chiral centre at the $\alpha$-carbon and can therefore exist as $R(-)$ or $S(+)$ enantiomeric forms. The inactive $R(-)$ enantiomer undergoes a unidirectional chiral inversion in vivo to $S(+)$, which is the species displaying anti-inflammatory activity. ${ }^{12-15}$ Following a single dose administration of immediate-release ibuprofen preparations, the peak plasma drug concentration was observed at $3 \mathrm{~h}$ postdose. Moreover, this drug is characterized by a rapid onset of pharmacological actions, with relatively little associated gastric disturbance, the blood plasma half-life lying between 2 and 3 h. ${ }^{16,17}$ This short half-life,
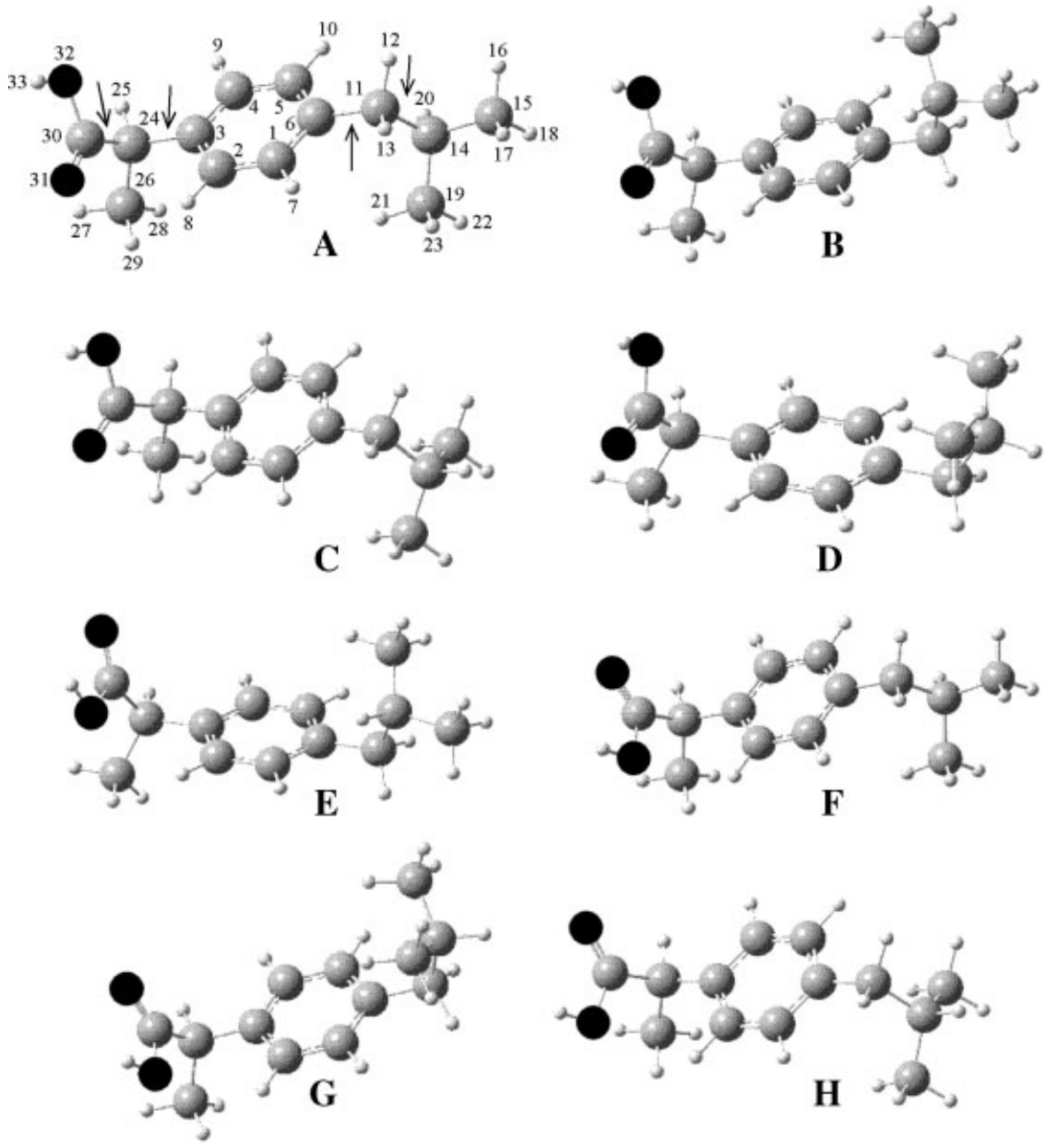

Figure 1. (A-H) Schematic representation of the eight most stable conformers of the ibuprofen molecule. 
coupled to the low single administration dosage necessary, renders ibuprofen a good candidate for the development of new controlled-delivery formulations. ${ }^{18-21}$

The development of distinct ibuprofen hydrophilic matrix tablets using different excipients (e.g., swellable cellulose polymers) is presently the object of vigorous research, as extended-release (either constant or pulsed) dosage forms of a particular drug may often be beneficial. Thus, the knowledge of intermolecular interactions between ibuprofen and these polymers/excipients, which modulates the in vivo drug release process, is of the utmost importance. This may be achieved through optical vibrational spectroscopy (both Raman and FTIR), once the conformational behavior of the pure drug in the solid state is known. The present study aims at achieving this goal, which will hopefully allow carrying out future studies on ibuprofen tablets (composed of distinct drug/polymer/excipient mixtures).

To the best of our knowledge, the only conformational study of ibuprofen reported to date was done by crystallographic database searching and potential energy calculations using the semi-empirical AM1 method. ${ }^{22}$

In the present work, a complete conformational study of ibuprofen was thus undertaken by quantum mechanics density functional theory (DFT) calculations coupled to Raman spectroscopy. The FTIR spectrum of pure ibuprofen was also analyzed, in order to explore the well known complementary between these two optical vibrational spectroscopy techniques.

\section{MATERIALS AND METHODS}

\section{Material}

Ibuprofen batch no. 9907257 was purchased from Knoll, Nottingham, England.

\section{Methods}

\section{Raman Spectroscopy}

The Raman spectra were obtained on a triple monochromator Jobin-Yvon T64000 Raman system (focal distance $0.640 \mathrm{~m}$, aperture $f / 7.5$ ) equipped with holographic gratings of 1800 grooves $\cdot \mathrm{mm}^{-1}$. The premonochromator stage was used in the subtractive mode. The detection system was liquid nitrogen cooled nonintensified
$578 \times 385$ pixel $\left(1 / 2^{\prime \prime}\right)$ charge coupled device $(\mathrm{CCD})$ chip. A coherent (model Innova 300-05) $\mathrm{Ar}^{+}$laser was used as light source, the output of which at $514.5 \mathrm{~nm}$ was adjusted to provide $35 \mathrm{~mW}$ at the sample position. A $90^{\circ}$ geometry, between the incident radiation and the collecting system, was employed. The entrance slit was set to $200 \mu \mathrm{m}$ and the slit between the premonochromator and the spectrograph was opened to $12 \mathrm{~mm}$. An integration time of $3 \mathrm{~s}$ and 10-15 scans were used in all experiments.

Samples were sealed in Kimax glass capillary tubes of $0.8 \mathrm{~mm}$ inner diameter. Under the abovementioned conditions, the error in wave numbers was estimated to be within $1 \mathrm{~cm}^{-1}$.

\section{FTIR Spectroscopy}

Infrared spectra of ibuprofen in $\mathrm{KBr}$ disks (ca. 5\% $(\mathrm{w} / \mathrm{w}))$ were recorded at room temperature on a Nicolet Model 740 FTIR spectrometer, in the range $400-4000 \mathrm{~cm}^{-1}$, using a globar source, a Ge/ $\mathrm{KBr}$ beamsplitter, a DTGS detector. The spectra were collected in 32 scans to a 16384 data points file (resolution ca. $2 \mathrm{~cm}^{-1}$ ) and subject to a HappGenzel apodization. The errors in wave numbers were estimated to less than $1 \mathrm{~cm}^{-1}$.

\section{DFT Calculations}

The molecular orbital calculations were carried out with the GAUSSIAN 03W program, ${ }^{23}$ within the DFT approach, using the B3LYP method, which includes a mixture of Hartree-Fock (HF) and DFT exchange terms. The gradient-corrected correlation functional was used, ${ }^{24,25}$ parameterized after Becke, ${ }^{26,27}$ along with the double-zeta split valence basis set $6-31 \mathrm{G}^{*}{ }^{28}$

Molecular geometries were fully optimized by the Berny algorithm, using redundant internal coordinates $^{29}$ : the bond lengths to within ca. $0.1 \mathrm{pm}$ and the bond angles to within ca. $0.1^{\circ}$. The final root-mean-square (rms) gradients were always less than $3 \times 10^{-4}$ Hartree $\cdot b h o h r^{-1}$ or Hartree $\cdot$ radian $^{-1}$. In order to study the barriers to internal rotation, the geometries were optimized for different fixed internal rotation angles.

The potential-energy profiles for rotation around several bonds within the molecule were obtained by scanning the correspondent dihedral angles by $15^{\circ}$ steps. The quantitative deconvolution of these profiles was based on least-squares fitted Fourier type functions of a relevant 
torsional angle,

$$
V=V_{0}+\sum_{n=1}^{4} \frac{1}{2} V_{n}[1-\cos (n \tau)]+\sum_{m=1}^{4} V_{m}^{\prime} \sin (m \tau)
$$

where $\tau$ represents the $\mathrm{O}^{31} \mathrm{C}^{30} \mathrm{C}^{24} \mathrm{C}^{3}, \mathrm{HC}^{24} \mathrm{C}^{3}$ $\mathrm{C}^{4}, \mathrm{C}^{1} \mathrm{C}^{6} \mathrm{C}^{11} \mathrm{C}^{14}$, or $\mathrm{C}^{6} \mathrm{C}^{11} \mathrm{C}^{14} \mathrm{H}$ dihedrals (Fig. 1), and $V$ are functional values that correspond to potential energy differences relative to a reference value $\left(V_{0}\right.$, the energy corresponding to a dihedral angle of $0^{\circ}$ ). According to the specific profile under study, different combinations of cosine and sine term were used (from 3 to 6).

Orbital interactions were determined using the natural bond orbital (NBO) approach from the donor-acceptor viewpoint ${ }^{30}$ applied to the wave functions, at the $\mathrm{B} 3 \mathrm{LYP} / 6-31 \mathrm{G}^{*}$ level of calculation. Routines for this kind of calculation are included in the GAUSSIAN 03W package, which convert the DFT molecular orbitals in a set of NBO orbitals, which constitute a hypothetical Lewis structure with strictly localized electron pairs. In this NBO formulation, delocalization arises from interactions between occupied bonding and antibonding orbitals and is represented by off-diagonal terms in the Kohn-Sham matrix. ${ }^{31}$

\section{RESULTS AND DISCUSSION}

\section{Conformational Analysis}

Ibuprofen can adopt different conformations, mainly by varying the dihedral angles around the $\mathrm{C}^{30}-\mathrm{C}^{24}, \mathrm{C}^{24}-\mathrm{C}^{3}, \mathrm{C}^{6}-\mathrm{C}^{11}$, and $\mathrm{C}^{11}-\mathrm{C}^{14}$ bonds (Fig. 1A). Moreover, rotational isomerism is also possible within the $\mathrm{O}=\mathrm{C}-\mathrm{O}-\mathrm{H}$ group, giving rise to either s-cis $\left(0^{\circ}\right)$ or s-trans $\left(180^{\circ}\right)$ stable geometries. Several studies performed on carboxylic containing molecules ${ }^{32-34}$ have demonstrated that, in the absence of intramolecular stabilizing interactions, the s-cis arrangements were found to be significantly more stable (ca. $20 \mathrm{kJmol}^{-1}$ ) than their s-trans counterparts. Thus, in the present study only those geometries displaying $\mathrm{O}=\mathrm{C}-\mathrm{O}-\mathrm{H}$ dihedrals equal to ca. $0^{\circ}$ were considered.

The eight different optimized conformations represented in Figure 1 were found to correspond to minima in the potential energy surface. This was verified by the absence of DFT calculated imaginary (negative) frequencies. Table 1 comprises the conformational energy differences, dipole moments, rotational constants, and thermochemical data (at $298.15 \mathrm{~K}$ and $1 \mathrm{~atm}$ ) for all the ibuprofen conformers presently calculated.

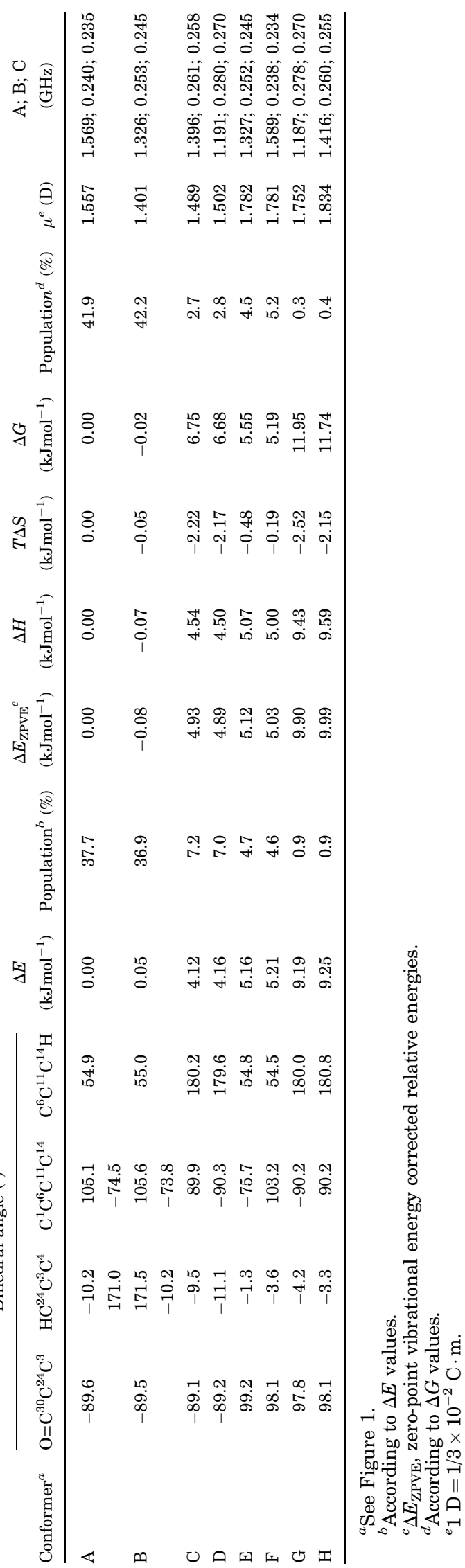


Table 2. Experimental (Single-Crystal Pulsed Neutron Diffraction ${ }^{35}$ ) and Calculated (B3LYP/6-31G*) Geometrical Parameters for Ibuprofen

Coordinate $^{a} \quad$ Experimental Calculated $^{b}$ Calculated $^{c}$

Bond length (pm)

$\begin{array}{llll}\mathrm{C}^{30}-\mathrm{O}^{32} & 1.306 & 1.356 & 1.355 \\ \mathrm{C}^{30}-\mathrm{O}^{31} & 1.204 & 1.211 & 1.213 \\ \mathrm{C}^{30}-\mathrm{C}^{24} & 1.503 & 1.526 & 1.523 \\ \mathrm{C}^{24}-\mathrm{C}^{26} & 1.500 & 1.535 & 1.538 \\ \mathrm{C}^{24}-\mathrm{C}^{3} & 1.525 & 1.530 & 1.528 \\ \mathrm{C}^{3}-\mathrm{C}^{4} & 1.374 & 1.401 & 1.400 \\ \mathrm{C}^{4}-\mathrm{C}^{5} & 1.376 & 1.393 & 1.394 \\ \mathrm{C}^{5}-\mathrm{C}^{6} & 1.392 & 1.402 & 1.402 \\ \mathrm{C}^{6}-\mathrm{C}^{1} & 1.380 & 1.400 & 1.401 \\ \mathrm{C}^{1}-\mathrm{C}^{2} & 1.396 & 1.395 & 1.395 \\ \mathrm{C}^{2}-\mathrm{C}^{3} & 1.380 & 1.400 & 1.401 \\ \mathrm{C}^{6}-\mathrm{C}^{11} & 1.493 & 1.514 & 1.514 \\ \mathrm{C}^{11}-\mathrm{C}^{14} & 1.529 & 1.550 & 1.550 \\ \mathrm{C}^{14}-\mathrm{C}^{15} & 1.508 & 1.535 & 1.535 \\ \mathrm{C}^{14}-\mathrm{C}^{19} & 1.519 & 1.534 & 1.535 \\ \mathrm{O}^{32}-\mathrm{H}^{33} & 0.963 & 0.976 & 0.976 \\ \mathrm{C}^{24}-\mathrm{H}^{25} & 1.091 & 1.096 & 1.095 \\ \mathrm{C}^{26}-\mathrm{H}^{29} & 1.081 & 1.093 & 1.093 \\ \mathrm{C}^{26}-\mathrm{H}^{27} & 1.053 & 1.095 & 1.096 \\ \mathrm{C}^{26}-\mathrm{H}^{28} & 1.073 & 1.094 & 1.094 \\ \mathrm{C}^{4}-\mathrm{H}^{9} & 1.103 & 1.087 & 1.088 \\ \mathrm{C}^{5}-\mathrm{H}^{10} & 1.041 & 1.088 & 1.088 \\ \mathrm{C}^{1}-\mathrm{H}^{7} & 1.065 & 1.088 & 1.088 \\ \mathrm{C}^{2}-\mathrm{H}^{8} & 1.077 & 1.086 & 1.087 \\ \mathrm{C}^{11}-\mathrm{H}^{13} & 1.101 & 1.099 & 1.099 \\ \mathrm{C}^{11}-\mathrm{H}^{12} & 1.102 & 1.099 & 1.099 \\ \mathrm{C}^{14}-\mathrm{H}^{20} & 1.085 & 1.100 & 1.100 \\ \mathrm{C}^{15}-\mathrm{H}^{17} & 1.061 & 1.098 & 1.098 \\ \mathrm{C}^{15}-\mathrm{H}^{16} & 1.097 & 1.097 \\ \mathrm{C}^{15}-\mathrm{H}^{18} & & 1.096 & 1.096 \\ \mathrm{C}^{19}-\mathrm{H}^{21} & 1.095 & 1.095 \\ \mathrm{C}^{19}-\mathrm{H}^{22} & 1.096 & 1.096 \\ \mathrm{C}^{19}-\mathrm{H}^{23} & 1.098 & 1.098\end{array}$

Bond angle $\left(^{\circ}\right)$

$\begin{array}{llll}\mathrm{O}^{32}-\mathrm{C}^{30}-\mathrm{O}^{31} & 123.4 & 122.5 & 122.4 \\ \mathrm{O}^{32}-\mathrm{C}^{30}-\mathrm{C}^{24} & 115.4 & 111.7 & 111.9 \\ \mathrm{O}^{31}-\mathrm{C}^{30}-\mathrm{C}^{24} & 121.1 & 125.7 & 125.7 \\ \mathrm{C}_{30}-\mathrm{C}_{24}-\mathrm{C}_{26} & 111.7 & 110.2 & 110.4 \\ \mathrm{C}_{30}-\mathrm{C}_{24}-\mathrm{C}_{3} & 106.7 & 108.5 & 109.4 \\ \mathrm{C}_{26}-\mathrm{C}_{24}-\mathrm{C}_{3} & 114.4 & 114.2 & 112.3 \\ \mathrm{C}_{24}-\mathrm{C}_{3}-\mathrm{C}_{4} & 120.9 & 120.1 & 120.5 \\ \mathrm{C}^{3}-\mathrm{C}^{4}-\mathrm{C}^{5} & 121.6 & 121.0 & 120.8 \\ \mathrm{C}^{4}-\mathrm{C}^{5}-\mathrm{C}^{6} & 120.7 & 121.2 & 121.2 \\ \mathrm{C}^{5}-\mathrm{C}^{6}-\mathrm{C}^{1} & 118.0 & 117.6 & 117.7 \\ \mathrm{C}^{6}-\mathrm{C}^{1}-\mathrm{C}^{2} & 120.7 & 121.4 & 121.4 \\ \mathrm{C}^{1}-\mathrm{C}^{2}-\mathrm{C}^{3} & 120.7 & 120.7 & 120.6 \\ \mathrm{C}^{2}-\mathrm{C}^{3}-\mathrm{C}^{4} & 118.2 & 118.1 & 118.3\end{array}$

Table 2. (Continued)

\begin{tabular}{|c|c|c|c|}
\hline Coordinate $^{a}$ & Experimental & Calculated $^{b}$ & Calculated $^{c}$ \\
\hline $\mathrm{C}^{2}-\mathrm{C}^{3}-\mathrm{C}^{24}$ & 120.9 & 121.7 & 121.1 \\
\hline$C^{5}-C^{6}-C^{11}$ & 120.2 & 120.7 & 120.7 \\
\hline $\mathrm{C}^{1}-\mathrm{C}^{6}-\mathrm{C}^{11}$ & 121.8 & 121.7 & 121.6 \\
\hline $\mathrm{C}^{6}-\mathrm{C}^{11}-\mathrm{C}^{14}$ & 113.9 & 114.6 & 114.6 \\
\hline $\mathrm{C}^{11}-\mathrm{C}^{14}-\mathrm{C}^{15}$ & 110.1 & 110.3 & 110.3 \\
\hline $\mathrm{C}^{11}-\mathrm{C}^{14}-\mathrm{C}^{19}$ & 111.5 & 112.0 & 112.0 \\
\hline $\mathrm{C}^{15}-\mathrm{C}^{14}-\mathrm{C}^{19}$ & 111.5 & 111.0 & 111.0 \\
\hline \multicolumn{4}{|l|}{ Torsional angle $\left({ }^{\circ}\right)$} \\
\hline $\mathrm{O}^{31}-\mathrm{C}^{30}-\mathrm{C}^{24}-\mathrm{C}^{3}$ & -89.6 & -95.5 & -89.6 \\
\hline $\mathrm{O}^{32}-\mathrm{C}^{30}-\mathrm{C}^{24}-\mathrm{C}^{3}$ & 88.7 & 83.0 & 89.0 \\
\hline $\mathrm{H}^{33}-\mathrm{O}^{32}-\mathrm{C}^{30}-\mathrm{O}^{31}$ & -3.3 & 1.2 & 1.5 \\
\hline $\mathrm{H}^{33}-\mathrm{O}^{32}-\mathrm{C}^{30}-\mathrm{C}^{24}$ & -175.1 & -176.6 & -177.2 \\
\hline $\mathrm{O}^{31}-\mathrm{C}^{30}-\mathrm{C}^{24}-\mathrm{C}^{26}$ & 36.0 & 30.2 & 34.4 \\
\hline $\mathrm{H}^{25}-\mathrm{C}^{24}-\mathrm{C}^{3}-\mathrm{C}^{4}$ & 19.8 & 19.8 & -10.2 \\
\hline $\mathrm{C}^{26}-\mathrm{C}^{24}-\mathrm{C}^{3}-\mathrm{C}^{4}$ & 140.5 & 140.6 & 110.6 \\
\hline $\mathrm{C}^{30}-\mathrm{C}^{24}-\mathrm{C}^{3}-\mathrm{C}^{4}$ & -95.5 & -96.0 & -126.6 \\
\hline $\mathrm{C}^{24}-\mathrm{C}^{3}-\mathrm{C}^{4}-\mathrm{C}^{5}$ & -177.7 & 178.5 & -178.2 \\
\hline $\mathrm{C}^{1}-\mathrm{C}^{6}-\mathrm{C}^{11}-\mathrm{C}^{14}$ & 102.1 & 103.9 & 105.1 \\
\hline $\mathrm{C}^{6}-\mathrm{C}^{11}-\mathrm{C}^{14}-\mathrm{C}^{15}$ & 168.5 & 171.7 & 172.4 \\
\hline $\mathrm{C}^{6}-\mathrm{C}^{11}-\mathrm{C}^{14}-\mathrm{H}^{20}$ & 50.4 & 54.3 & 54.9 \\
\hline $\mathrm{C}^{6}-\mathrm{C}^{11}-\mathrm{C}^{14}-\mathrm{C}^{19}$ & -67.1 & -64.0 & -63.4 \\
\hline$\Delta E\left(\mathrm{kJmol}^{-1}\right)^{d}$ & 5.12 & 2.97 & 0.00 \\
\hline
\end{tabular}

${ }^{a}$ See Figure 1 for atom numbering.

${ }^{b}$ Complete optimization based on the experimental geometry, for a fixed $\mathrm{H}^{25}-\mathrm{C}^{24}-\mathrm{C}^{3}-\mathrm{C}^{4}$ dihedral at $19.8^{\circ}$.

${ }^{c}$ Most stable calculated conformer (A).

${ }^{d}$ Calculated (B3LYP/6-31G*) relative energy values.

It is noteworthy that the two sets of dihedrals $\mathrm{HC}^{24} \mathrm{C}^{3} \mathrm{C}^{4}=-10.2^{\circ}$ or $105.1^{\circ}$ and $\mathrm{C}^{1} \mathrm{C}^{6} \mathrm{C}^{11}$ $\mathrm{C}^{14}=171.0^{\circ}$ or $-74.5^{\circ}$ correspond to conformer $\mathrm{A}$, since they yield identical structures, the same occurring for B (Tab. 1).

The ibuprofen molecule can be considered as a para-substituted phenyl ring. Interestingly, the relative orientation of the substituents hardly affects the conformational stability of this system. In fact, these can be either below or above the ring plane, or even in opposite sides (Fig. 1). Actually, the rotations around the $\mathrm{C}^{24}-\mathrm{C}^{3}$ and $\mathrm{C}^{6}-\mathrm{C}^{11}$ bonds are not correlated, which is evidenced by comparing conformers (both geometries and energies) $\mathrm{A}$ versus $B, C$ versus $D, E$ versus $F$, and $G$ versus $H$ (Fig. 1 and Table 1). Consequently, the existence of not more than four energetically distinct conformations may be considered: $\mathrm{AB}(\Delta E \approx$ $\left.0 \mathrm{kJmol}^{-1}\right), \mathrm{CD}\left(\Delta E \approx 4.1 \mathrm{kJmol}^{-1}\right), \mathrm{EF}(\Delta E \approx$ $\left.5.2 \mathrm{kJmol}^{-1}\right)$, and $\mathrm{GH}\left(\Delta E \approx 9.2 \mathrm{kJmol}^{-1}\right.$ ) (Tab. 1). These energy differences correspond to room temperature populations of $75,14,9$, and $2 \%$, respectively. 
However, although the two structures in each of these groups are virtually degenerated, their rotational constants and, in some cases, their dipole moments do not follow the same energetic trend (Tab. 1). This would be expected, since the change in the relative orientation of the substituents, which leads to different rotational constants and dipole moments, was found not to affect the corresponding conformational stability (Fig. 1).

The estimation of the $\Delta E$ based populations assumed similar entropy contributions to the free energy of the distinct conformers. Nevertheless, this assumption is not strictly correct since the smaller conformational flexibility of $\mathrm{C}, \mathrm{D}, \mathrm{G}$, and $\mathrm{H}\left(\mathrm{C}^{6} \mathrm{C}^{11} \mathrm{C}^{14} \mathrm{H}\right.$ ca. $\left.180^{\circ}\right)$ provides less significant entropy terms $(T \Delta S)$ and, accordingly, an increase of the corresponding free energy differences relative to the most stable conformers: $\mathrm{AB}$ $\left(\Delta G \approx 0 \mathrm{kJmol}^{-1}\right), \mathrm{CD}\left(\Delta G \approx 6.7 \mathrm{kJmol}^{-1}\right), \mathrm{EF}$ $\left(\Delta G \approx 5.4 \mathrm{kJmol}^{-1}\right)$, and $\mathrm{GH}\left(\Delta G \approx 11.8 \mathrm{kJmol}^{-1}\right)$ (Tab. 1). These free energy differences correspond to room temperature Gibbs populations of 84,5 , 10 , and $1 \%$, respectively. Moreover, if entropy contributions are considered, the $\mathrm{B}$ conformer becomes the most stable one $\left(\Delta G_{\mathrm{A}-\mathrm{B}} \approx\right.$ $-0.02 \mathrm{kJmol}^{-1}$ ).

In aqueous solutions, however, these populations are expected to be slightly altered, since the conformers displaying higher dipole moments $(\mathrm{E}$, $\mathrm{F}, \mathrm{G}$, and $\mathrm{H}$ ) are energetically favored. The effect of the aqueous environment can even overrule the energetic degeneracy discussed above: particularly for the $\mathrm{AB}$ pair, the population of $\mathrm{A}$ $(\mu=1.557 \mathrm{D})$ will certainly increase relative to $\mathrm{B}(\mu=1.401 \mathrm{D})$.

Table 2 comprises the single-crystal pulsed neutron diffraction refined geometry reported for ibuprofen $^{35}$, as well as some B3LYP/6-31G* optimized geometries (results for the other conformers and for angle parameters involving hydrogen atoms are available from the authors upon request). The DFT structural parameters presently obtained are in quite good agreement with the experimental ones, although there are some discrepancies both in bond distances (e.g., $\mathrm{C}^{30}-\mathrm{O}^{32}$ and $\mathrm{C}^{24}-\mathrm{C}^{26}$ ) and angles (e.g., $\mathrm{O}^{31}$ $\mathrm{C}^{30}-\mathrm{C}^{24}$ ) which can be a consequence of the crystal packing. The energy difference between the most stable ibuprofen conformer (B3LYP/6-31G* total geometry optimization) and the one obtained from the experimental geometry (B3LYP/6-31G* single-point calculation) is $5.12 \mathrm{kJmol}^{-1}$, due to two main factors: (i) conformational rearrange- ments around the $\mathrm{C}^{24}-\mathrm{C}^{3}$ bond (ca. $30^{\circ}$ internal rotation, Table 2) which are required for an efficient molecular packing in the crystalline structure; (ii) the optimization process did not allow for the relaxation of the other geometrical parameters. In order to abolish the latter and obtain a more accurate value for the energy gap associated to that rearrangement, a total geometry optimization was performed for a fixed $\mathrm{H}^{25}-\mathrm{C}^{24}-\mathrm{C}^{3}-\mathrm{C}^{4}$ dihedral angle (Tab. 2), which yielded energy of $2.97 \mathrm{kJmol}^{-1}$.

Rotational isomerism in this type of compounds, comprising aromatic, carboxylic and alkylic groups is dependent on several factors, namely steric, dipolar, mesomeric, and hiperconjugative effects, and hydrogen bond interactions. Furthermore, the relative importance of intra versus intermolecular interactions (e.g., dimer formation) has often proved, in several systems, to be determinant of their conformational preferences, either as pure compounds or in solution.

Potential energy profiles for internal rotation around different bonds within the ibuprofen molecule $\left(\mathrm{C}^{30}-\mathrm{C}^{24}, \mathrm{C}^{24}-\mathrm{C}^{3}, \mathrm{C}^{6}-\mathrm{C}^{11}\right.$, and $\mathrm{C}^{11}-\mathrm{C}^{14}$ bonds) were obtained, by scanning the corresponding torsional angles.

\section{Rotation around the $C^{30}-C^{24}$}

The $\mathrm{C}^{30}-\mathrm{C}^{24}$ rotation converts conformers $\mathrm{A}$ to $\mathrm{F}$ (Fig. 2a). The energy difference between these two arrangements $\left(\Delta E_{\mathrm{F}-\mathrm{A}}\right)$ and the corresponding clockwise internal rotation barrier $(\mathrm{A} \rightarrow \mathrm{F})$ being $5.21 \mathrm{kJmol}^{-1}$ and $9.9 \mathrm{kJmol}^{-1}$, respectively. The anticlockwise rotation, in turn, has a $11.3 \mathrm{kJmol}^{-1}$ barrier. The presence of the aromatic ring is responsible for obvious differences in the conformational behavior of the ibuprofen propionic moiety, when compared to previous studies on both propionic and 2-methylpropionic acids. ${ }^{36-38}$ Actually, latter the preferred conformations around the $\mathrm{C} \alpha-\mathrm{C}$ bond are those displaying $\alpha$ substituents with either syn or skew orientations relative to the $\mathrm{C}=\mathrm{O}$ bond $\left(\mathrm{CCC}=\mathrm{O}\right.$ equal to $0^{\circ}$ or $\pm 120^{\circ}$, respectively). The analogous geometries for ibuprofen were also found to be favored, as the Fourier term in $V_{3}$ (Fig. 2b) displays an intermediate value $\left(2.12 \mathrm{kJmol}^{-1}\right)$, despite the largely dominant contribution being represented by a cosine component in $V_{2}\left(-5.66 \mathrm{kJmol}^{-1}\right)$. This term exhibits maxima for $\mathrm{C}^{3} \mathrm{C}^{24} \mathrm{C}^{30}=\mathrm{O}^{31}$ equal to $0^{\circ}$ and $180^{\circ}$, and minima for $-90^{\circ}$ and $90^{\circ}$, reflecting the preference for geometries that favor $\pi$-delocalization between the $\mathrm{OC}=\mathrm{O}$ group and the 
$\mathbf{a}$

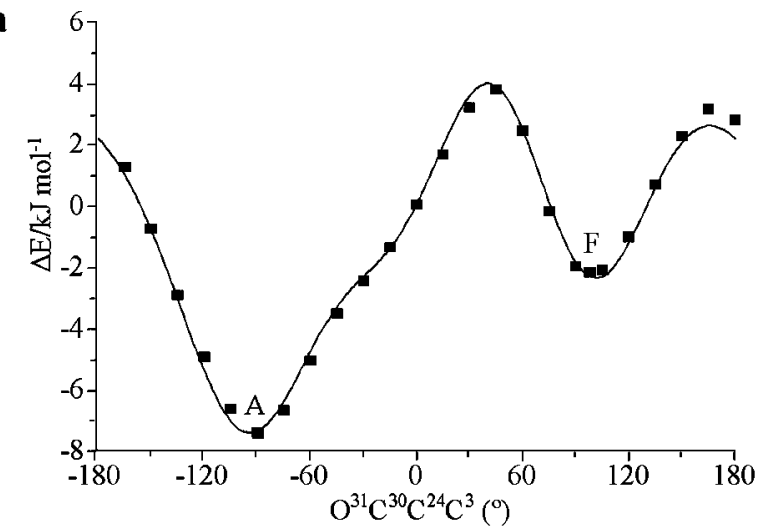

b

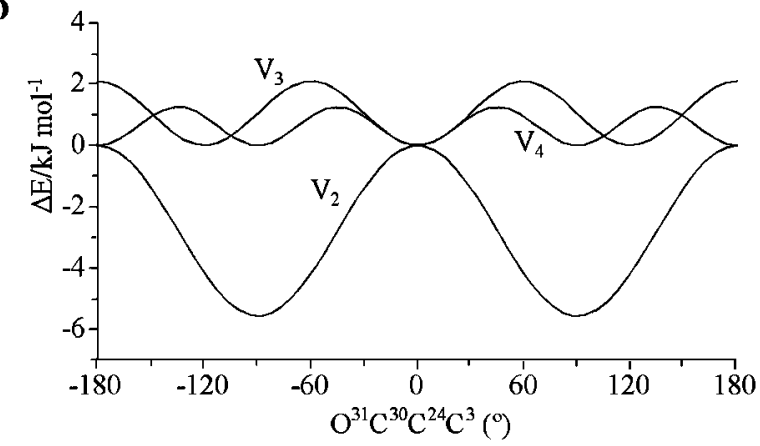

c

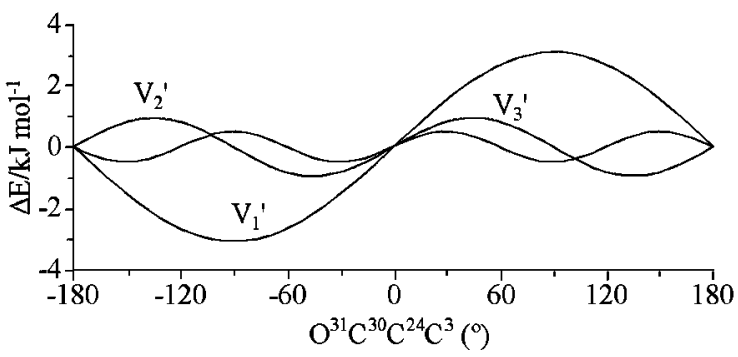

Figure 2. Optimized (B3LYP/6-31G*) conformational energy profile for the internal rotation around the $\mathrm{O}^{30}-\mathrm{C}^{24}$ bond of ibuprofen (a) and its Fourier deconvolution (b and c). $V_{2}=-5.66 \mathrm{kJmol}^{-1}, V_{3}=2.12 \mathrm{kJmol}^{-1}$, $V_{4}=1.27 \mathrm{kJmol}^{-1}, V_{1}^{\prime}=3.26 \mathrm{kJmol}^{-1}, V_{2}^{\prime}=0.87 \mathrm{kJmol}^{-1}$, and $V^{\prime} 3=0.53 \mathrm{kJmol}^{-1}$.

aromatic ring, which are face-to-face (in-phase) in these conformations (Fig. 2b) (as opposed to the tilted, out-of-phase, relative orientations occurring in the other geometries). In fact, the results yielded by the NBO approach and donor-acceptor analysis based on localized orbitals, ${ }^{30}$ allow to conclude that $\pi\left(\mathrm{C}^{2}-\mathrm{C}^{3}\right) \rightarrow \pi^{*}\left(\mathrm{C}^{30}=\mathrm{O}^{31}\right)$ is the key interaction occurring in these conformations, with a calculated stabilization energy of $8.54 \mathrm{kJmol}^{-1}$. Moreover, the $\pi\left(\mathrm{C}^{30}=\mathrm{O}^{31}\right) \rightarrow \sigma^{*}\left(\mathrm{C}^{3}-\mathrm{C}^{24}\right)$ and $\sigma\left(C^{3}-C^{24}\right) \rightarrow \pi^{*}\left(C^{30}=\mathrm{O}^{31}\right)$ interactions also contribute to the described stabilization. Thus, two minima were obtained for the ibuprofen $\mathrm{C}^{30}-\mathrm{C}^{24}$ rotational profile, for $\mathrm{C}^{3} \mathrm{C}^{24} \mathrm{C}^{30}=\mathrm{O}^{31}$ equal to $-89.6^{\circ}$ and $98.1^{\circ}$.

Furthermore, these two minima are not equivalent $\left(\Delta E_{\mathrm{F}-\mathrm{A}}=5.21 \mathrm{kJmol}^{-1}\right)$. In fact, the $V^{\prime}{ }_{1}$ sine term $\left(3.23 \mathrm{kJmol}^{-1}\right.$, Fig. 2c) favors the conformations displaying a negative $\mathrm{C}^{3} \mathrm{C}^{24} \mathrm{C}^{30}=\mathrm{O}^{31}$ dihedral angle, that is, for an equal orientation of the carbonyl and the $\alpha$-methyl group. Actually, these geometries allow the formation of stabilizing $\mathrm{C}=$ $\mathrm{O} \cdots \mathrm{H}$ close contacts, either with $\mathrm{H}^{27}, \mathrm{H}^{29}$, or $\mathrm{H}^{8}$ (Fig. 3). In fact, $\mathrm{H}_{8}$ displays the highest natural atomic charge $(0.247)$ as compared to the other aromatic hydrogens (ca. 0.234) (Fig. 3).

\section{Rotation around $C^{24}-C^{3}$}

The rotation $\mathrm{C}^{24}-\mathrm{C}^{3}$ interconverts conformers $\mathrm{A}$ and $\mathrm{B}$ (Fig. 4a), $\mathrm{HC}^{24} \mathrm{C}^{3} \mathrm{C}^{4}$ being equal to $-10.2^{\circ}$ and $171.5^{\circ}$, respectively. The corresponding internal conversion barrier is $13.5 \mathrm{kJmol}^{-1}$, both conformers having an equivalent potential energy $\left(\Delta E_{\mathrm{B}-\mathrm{A}}=0.05 \mathrm{kJmol}^{-1}\right)$. This evidences that the conformational stability of the ibuprofen molecule is not affected by the relative orientation of the substituents-either below or above the ring plane (conformer B, Fig. 1) or to opposite sides of this plane (conformer A, Fig. 1).

In the light of this result, ibuprofen can be regarded as both an $\alpha, \alpha$-disubstituted toluene on $\mathrm{C}^{24}$, and an $\alpha$-monosubstituted toluene on $\mathrm{C}^{11}$. Although hiperconjugative interactions constitute an acceptable basis for explaining the barriers for internal rotation around the $\mathrm{C}\left(\mathrm{sp}^{2}\right)-\mathrm{C}\left(\mathrm{sp}^{3}\right)$ bond in $\alpha$-substituted toluenes, this effect alone does not account satisfactorily for the conformational behavior of the more heavily substituted toluenes. In particular, when either heteroatoms or bulky $\alpha$ substituents are present, other effects, such as steric and electrostatic interactions, must be considered. $^{39}$

The values of the Fourier components of the potential energy profile for the $\mathrm{HC}^{24} \mathrm{C}^{3} \mathrm{C}^{4}$ dihedral

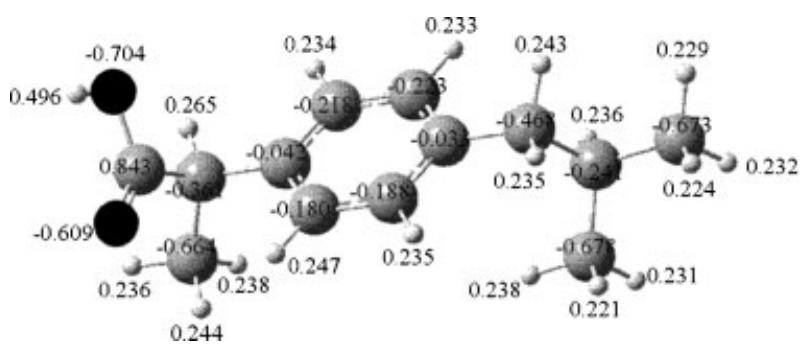

Figure 3. Calculated (B3LYP/6-31G*) natural atomic charges for the A conformer of ibuprofen. 


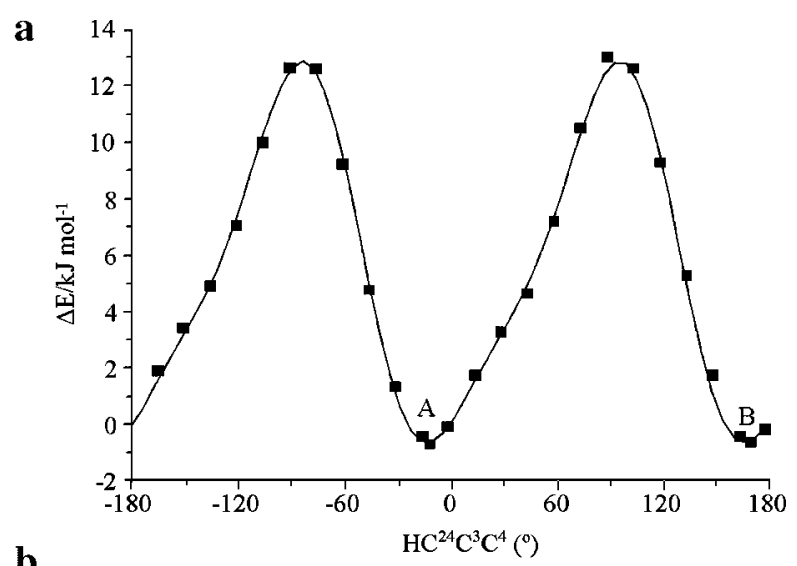

b

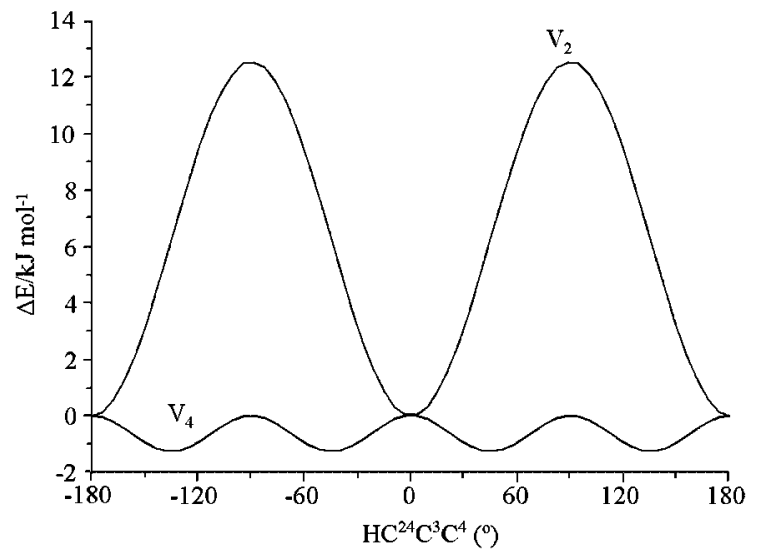

c

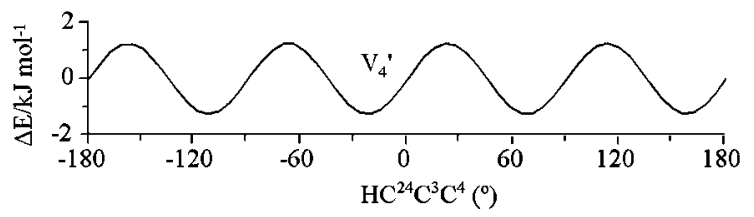

Figure 4. Optimized (B3LYP/6-31G*) conformational energy profile for the internal rotation around the $\mathrm{C}^{24} \mathrm{C}^{3}$ bond of ibuprofen (a) and its Fourier deconvolution (b and c). $V_{1}=6.31 \mathrm{kJmol}^{-1}, V_{2}=6.31 \mathrm{kJmol}^{-1}$, $V_{4}=-1.27 \mathrm{kJmol}^{-1}$, and $V_{4}^{\prime}=1.24 \mathrm{kJmol}^{-1}$.

(Figs. 4b and c), point to a leading contribution of a cosine term in $V_{2}\left(12.62 \mathrm{kJmol}^{-1}\right.$, Fig. $\left.4 \mathrm{~b}\right)$, reflecting a preference for trans and cis arrangements around the $\mathrm{HC}^{24}-\mathrm{C}^{3} \mathrm{C}^{4}$ bond, since these conformations tend to: (i) minimise steric hindrance between the bulkiest substituent groups ( $\alpha$-methyl and carboxyl) and the phenyl ring, by placing the former above and below the ring; (ii) maximize the attractive hydrogen bond type interactions between the $\mathrm{C}=\mathrm{O}$ carbonyl group and either $\mathrm{H}^{8}$ (in conformer $\mathrm{A}$ ) or $\mathrm{H}^{9}$ (in conformer $\mathrm{B})$, giving rise to a stabilizing six-membered intramolecular ring; (iii) favor both charge transfer $\quad \sigma\left(\mathrm{C}^{24}-\mathrm{H}^{25}\right) \rightarrow \sigma^{*}\left(\mathrm{C}^{2}-\mathrm{C}^{3}\right) \quad$ or $\quad \sigma\left(\mathrm{C}^{24}-\right.$ $\left.\mathrm{H}^{25}\right) \rightarrow \sigma^{*}\left(\mathrm{C}^{3}-\mathrm{C}^{4}\right)$ interactions, for $\mathrm{HC}^{24} \mathrm{C}^{3} \mathrm{C}^{4}$ equal to $0^{\circ}$ or $180^{\circ}$, respectively; (iv) maximize interactions between anti-bonding $\pi$ orbitals from the carbonyl and phenyl groups, $\pi^{*}\left(\mathrm{C}^{30}=\right.$ $\left.\mathrm{O}^{31}\right) \rightarrow \pi^{*}\left(\mathrm{C}^{2}-\mathrm{C}^{3}\right)$.

Also, the sine term $V_{4}^{\prime}\left(1.24 \mathrm{kJmol}^{-1}\right.$, Fig. $\left.4 \mathrm{c}\right)$ is due to electrostatic factors occurring within the molecule. Indeed, it displays energy maxima when destabilizing interactions occur between the positively charged methyl $\mathrm{H}^{28}$ or $\mathrm{H}^{29}$ atoms and the aromatic $\mathrm{H}^{8}$ or $\mathrm{H}^{9}$. In contrast, it exhibits energy minima whenever the methyl group is situated in such way as to minimize this type of repulsive close contacts: (i) either above or below the ring plane, in a perpendicular relative position; (ii) or displaying $\mathrm{C}^{26}$ and $\mathrm{H}^{27}$ in the aromatic plane, and $\mathrm{H}^{28}$ and $\mathrm{H}^{29}$ symmetrically located relative to $\mathrm{H}^{8}$ or $\mathrm{H}^{9}$.

The Fourier term in $V_{4}\left(-1.27 \mathrm{~kJ} \mathrm{~mol}^{-1}\right.$, Fig. 4b), in turn, accounts for hiperconjugative stabilizing $\pi($ ring $) \rightarrow \sigma^{*}\left(C^{24}-C^{26}\right)$ and $\sigma\left(C^{24}-\right.$ $\left.\mathrm{C}^{26}\right) \rightarrow \pi^{*}$ (ring) interactions, for $\mathrm{HC}^{24} \mathrm{C}^{3} \mathrm{C}^{4}$ equal to $\pm 45^{\circ}$ and $\pm 135^{\circ}$. When compared to $V_{2}$ and $V_{4}^{\prime}$, this is a much smaller contribution to the overall potential energy profile of the $-\mathrm{CH}\left(\mathrm{CH}_{3}\right) \mathrm{COOH}$ rotor, which is indicative of the lesser significance of the hyperconjugative effect.

\section{Rotation around $C^{6}-C^{11}$}

Conformers A-B (Fig. 5a), for $\mathrm{C}^{1} \mathrm{C}^{6} \mathrm{C}^{11} \mathrm{C}^{14}$ equal to $-74.5^{\circ}$ and $105.6^{\circ}$, respectively, are also interconverted by rotation about $\mathrm{C}^{6}-\mathrm{C}^{11}$, with an internal barrier of $15.1 \mathrm{kJmol}^{-1}$, which is slightly higher than the one obtained for the $C^{24}-C^{3}$ rotation.

Considering the values obtained for the Fourier components of the potential energy profile of this internal rotation process (Figs $5 \mathrm{~b}$ and $5 \mathrm{c}$ ), it can be concluded that the dominant contributions are both $V_{2}\left(-9.39 \mathrm{kJmol}^{-1}\right)$ and $V_{2}^{\prime}\left(5.27 \mathrm{kJmol}^{-1}\right)$. The former accounts for: (i) steric hindrance minimization, when the bulky isobutyl group is away from the phenyl ring plan, corresponding to a $\mathrm{C}^{1} \mathrm{C}^{6} \mathrm{C}^{11} \mathrm{C}^{14}$ dihedral equal to $\pm 90^{\circ}$; (ii) maximization of the $\sigma($ ring $) \rightarrow \sigma^{*}\left(\mathrm{C}^{11}-\mathrm{H}\right), \quad \sigma\left(\mathrm{C}^{11}\right.$ $\mathrm{H}) \rightarrow \sigma^{*}($ ring $)$, and $\sigma($ ring $) \rightarrow \sigma^{*}\left(\mathrm{C}^{11}-\mathrm{C}^{15}\right)$ charge transfer processes. On the other hand, the $V_{2}^{\prime}$ sine term reflects the steric and electrostatic destabilizing interactions between the positively charged methyl $\mathrm{H}_{21}$ atom and the aromatic $\mathrm{H}^{7}$ or $\mathrm{H}^{10}$, displaying energy maxima for $\mathrm{C}^{1} \mathrm{C}^{6} \mathrm{C}^{11} \mathrm{C}^{14}$ equal to $-135^{\circ}$ and $45^{\circ}$ and energy minima for $-45^{\circ}$ and $135^{\circ}$. 


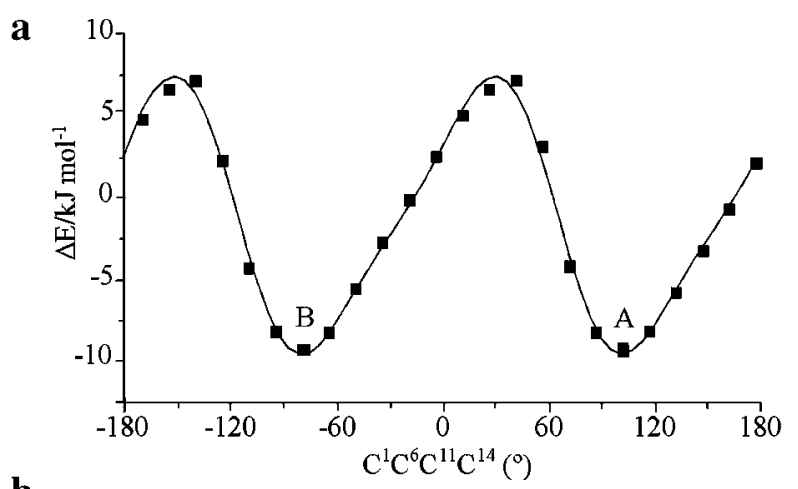

b

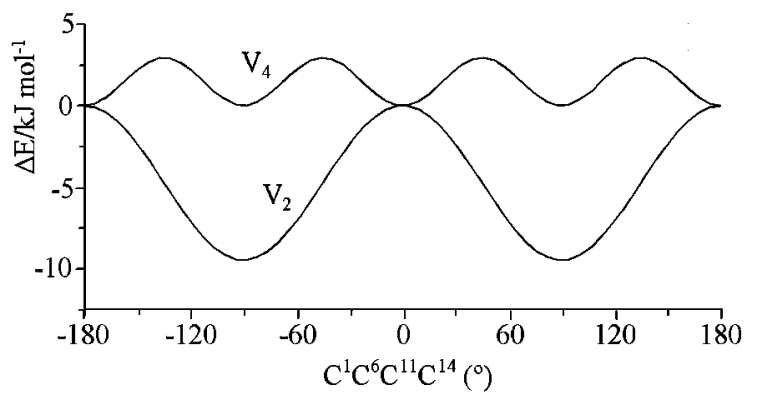

C

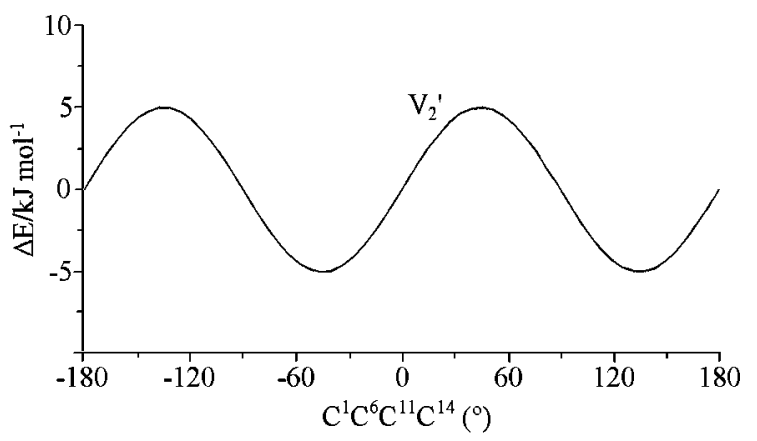

Figure 5. Optimized (B3LYP/6-31G*) conformational energy profile for the internal rotation around the $\mathrm{C}^{6}-\mathrm{C}^{11}$ bond of ibuprofen (a) and its Fourier deconvolution (b and c). $V_{2}=-9.39 \mathrm{kJmol}^{-1}$ and $V_{4}=$ $2.87 \mathrm{kJmol}^{-1}$ and $V_{2}^{\prime}=5.27 \mathrm{kJmol}^{-1}$.

The $V_{4}\left(2.87 \mathrm{kJmol}^{-1}\right)$ Fourier term, in turn, represents the donor and acceptor hyperconjugative contributions, with respect to the $\pi$ aromatic system, for each bond of the $-\mathrm{CH}_{2} \mathrm{C}$ rotor: $\pi$ (ring) $\rightarrow$ $\sigma^{*}\left(\mathrm{C}^{11}-\mathrm{H}\right), \sigma\left(\mathrm{C}^{11}-\mathrm{H}\right) \rightarrow \pi^{*}($ ring $), \sigma\left(\mathrm{C}^{11}-\mathrm{C}^{15}\right) \rightarrow \pi^{*}$ (ring). These were found to contribute additively to the hyperconjugative effect of the whole group. In fact, while for $\mathrm{C}^{1} \mathrm{C}^{6} \mathrm{C}^{11} \mathrm{C}^{14}$ equal to $\pm 90^{\circ}$ the $\sigma\left(\mathrm{C}^{11}-\mathrm{C}^{15}\right) \rightarrow \pi^{*}$ (ring) interplay is the predominant one, for the $0^{\circ}$ and $180^{\circ}$ conformations this effect occurs mainly through $\sigma\left(\mathrm{C}^{11}-\mathrm{H}\right) \rightarrow \pi^{*}$ (ring) interactions, the overall hyperconjugative stabilization being identical for the favored $0^{\circ}, \pm 90^{\circ}$, and $180^{\circ}$ arrangements. From the magnitude of this term, as compared to $V_{2}$ and $V_{2}^{\prime}$, it is possible to conclude that hyperconjugation plays a less impor- a

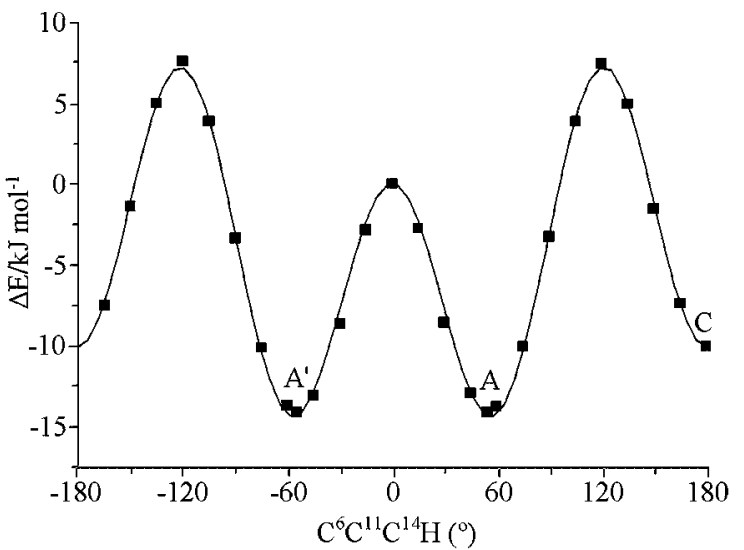

b

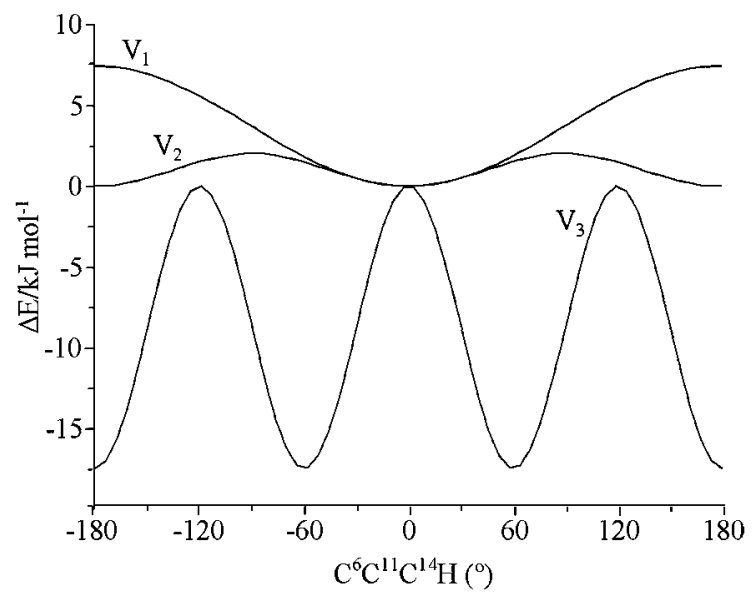

Figure 6. Optimized (B3LYP/6-31G*) conformational energy profile for the internal rotation around the $\mathrm{C}^{11}-\mathrm{C}^{14}$ bond of ibuprofen (a) and its Fourier deconvolution (b). $V_{1}=7.53 \mathrm{kJmol}^{-1}, V_{2}=2.07 \mathrm{kJmol}^{-1}$, and $V_{3}=-17.63 \mathrm{kJmol}^{-1}$.

tant role than steric and electrostatic interactions, for the rotation of the isobutyl fragment within the ibuprofen molecule.

\section{Rotation around the $C^{11}-C^{14}$}

$\mathrm{C}^{11}-\mathrm{C}^{14}$ rotation interconverts conformers $\mathrm{A}, \mathrm{C}$, and $\mathrm{A}^{\prime}$ (Fig. 6a), $\mathrm{C}^{6} \mathrm{C}^{11} \mathrm{C}^{14} \mathrm{H}$ being equal to $54.9^{\circ}$, $180.2^{\circ}$, and $-54.4^{\circ}$, respectively. This rotation is practically symmetric around $0^{\circ}$. Actually, the presence of the para-substituent is responsible for a slight asymmetry which renders $\mathrm{A}$ and $\mathrm{A}^{\prime}$ geometries not perfectly equivalent, although with identical conformational energies. The calculated value for the energy difference between conformers $\mathrm{C}$ and $\mathrm{A}, \Delta E_{\mathrm{C}-\mathrm{A}}$, is $4.12 \mathrm{kJmol}^{-1}$, the $\mathrm{A} \rightarrow \mathrm{C}$ and $\mathrm{A} \rightarrow \mathrm{A}^{\prime}$ barriers being equal to 21.5 and $14.3 \mathrm{kJmol}^{-1}$, respectively (Fig. 6a).

Considering a Fourier decomposition of this energy variation profile, it was verified that only 
the cosine terms need to be considered (Fig. 6b). The highest contribution was found to come from $V_{3}\left(-17.63 \mathrm{kJmol}^{-1}\right)$, thus favoring the staggered conformations, as expected for saturated hydrocarbons. The term in $V_{1}\left(7.53 \mathrm{kJmol}^{-1}\right)$ favors the cis arrangement relative to the trans, since the concurrent steric repulsions between the twomethyl groups from the isobutyl moiety (particularly $\mathrm{H}^{17}$ and $\mathrm{H}^{21}$ ) and the phenyl $\pi$ orbitals are expected to be very strong for this species. Thus, this contribution is responsible for the lower value of the $\mathrm{A} \rightarrow \mathrm{A}^{\prime}$ rotational barrier as compared to $\mathrm{A} \rightarrow \mathrm{C}$ (Fig. 6a).

\section{Vibrational Analysis}

The ibuprofen Raman spectrum, in the 100-1750 and 2700-3300 $\mathrm{cm}^{-1}$ regions, and the FTIR spectrum, in the $400-1750$ and $2700-3300 \mathrm{~cm}^{-1}$ intervals, for the solid state at room temperature, are represented in Figs. 7a and 7b, respectively. Table 3 comprises the experimental Raman and
FTIR wave numbers, as well as the $a b$ initio calculated frequencies for the two most stable conformers, A and B (Fig. 1). A quite good accordance was found between the experimental and calculated values, after scaling according to Scott and Radom ${ }^{40}$ in order to correct for the anharmonicity of the normal modes of vibration. Actually, since the calculated energy difference between $\mathrm{B}$ and the most stable A species is as small as $0.05 \mathrm{~kJ} \mathrm{~mol}^{-1}$, both these conformers may have significative populations at room temperature. Nevertheless, the calculated values for the most conformationally sensitive frequency region (below $600 \mathrm{~cm}^{-1}$ ) are remarkably consistent with the presence of conformer A alone. The bands at about 477,523 , and $586 \mathrm{~cm}^{-1}$, for instance, display an outstandingly good agreement with the calculated values for A conformer (472, 512, and $597 \mathrm{~cm}^{-1}$ ) when compared to the ones calculated for the B geometry.

Table 3 also contains a complete assignment of the ibuprofen observed FTIR and Raman bands to

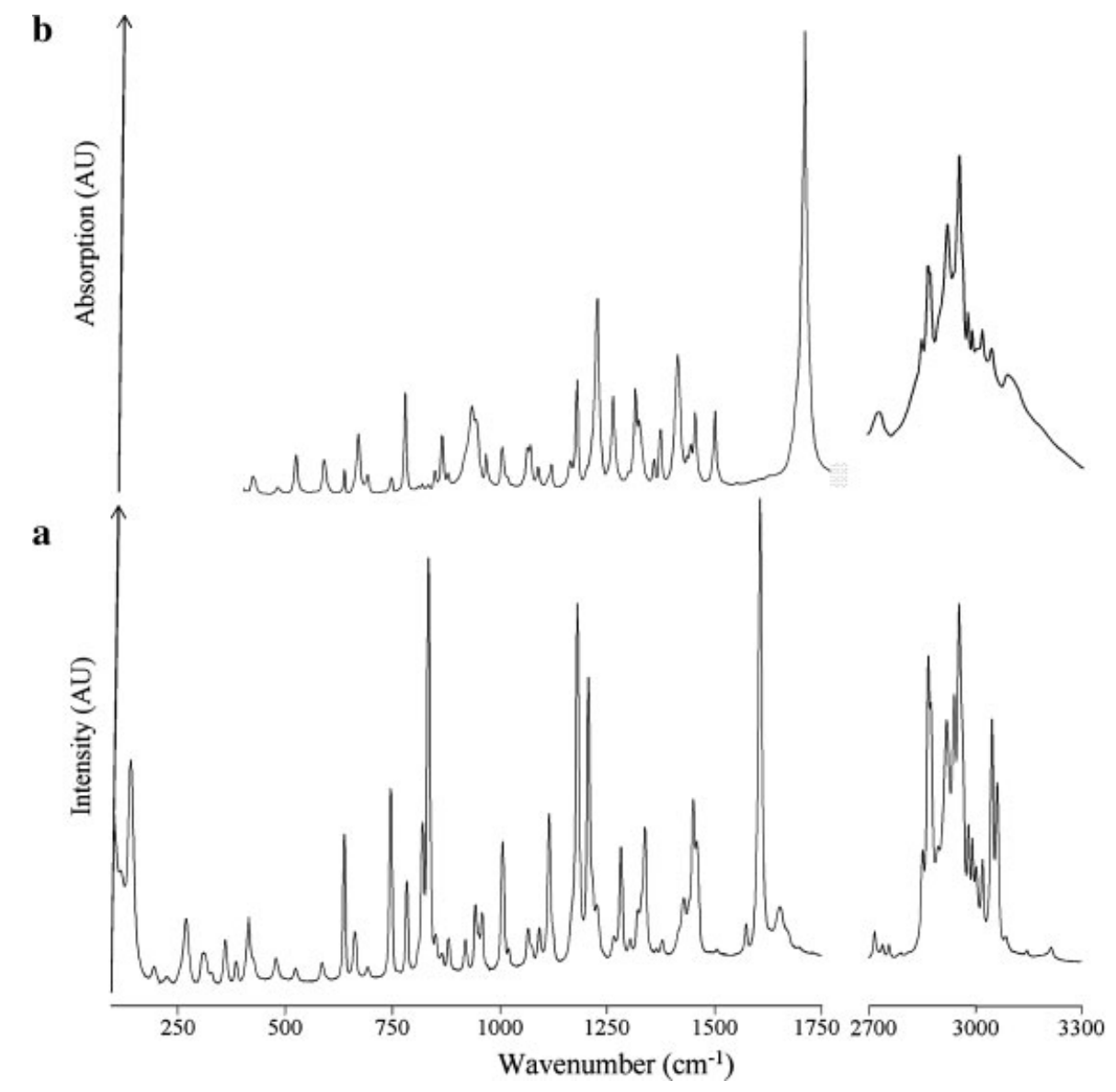

Figure 7. Vibrational optical spectra for solid ibuprofen. (a) Raman (100-1750 $\mathrm{cm}^{-1}$, 2700-3300 cm ${ }^{-1}$ ); (b) FTIR (400-1750 $\mathrm{cm}^{-1}, 2700-3300 \mathrm{~cm}^{-1}$, in a KBr disk). 
Table 3. Experimental (Raman and FTIR) and DFT-Calculated Harmonic wave numbers $\left(\mathrm{cm}^{-1}\right)$ and Intensities for Ibuprofen

\begin{tabular}{|c|c|c|c|c|}
\hline \multirow[b]{2}{*}{ Raman } & \multirow[b]{2}{*}{ FTIR } & \multicolumn{2}{|c|}{ Calculated $^{a}$} & \multirow[b]{2}{*}{ Approximate descriptions ${ }^{b}$} \\
\hline & & Conformer A & Conformer B & \\
\hline \multirow[t]{2}{*}{138} & & $106(3 ; 0)$ & $117(3 ; 0)$ & $\mathrm{C}^{6}-\mathrm{C}^{11}-\mathrm{C}^{14}, \mathrm{C}^{3}-\mathrm{C}^{24}-\mathrm{C}^{30}$ deformations \\
\hline & & $163(0 ; 0)$ & $148(0 ; 0)$ & $\mathrm{C}^{3}-\mathrm{C}^{24}-\mathrm{C}^{26}$ deformation \\
\hline 193 & & $216(0 ; 1)$ & $208(0 ; 1)$ & $\mathrm{C}^{26} \mathrm{H}_{3}-\mathrm{C}, \mathrm{C}^{19} \mathrm{H}_{3}-\mathrm{C}$ torsions \\
\hline \multirow[t]{3}{*}{222} & & $226(1 ; 0)$ & $224(0 ; 0)$ & $\mathrm{C}^{15} \mathrm{H}_{3}-\mathrm{C}, \mathrm{C}^{19} \mathrm{H}_{3}-\mathrm{C}$ torsions \\
\hline & & $231(0 ; 1)$ & $235(0 ; 1)$ & $\mathrm{C}^{26} \mathrm{H}_{3}-\mathrm{C}$ torsion \\
\hline & & $234(1 ; 0)$ & $244(2 ; 0)$ & $\mathrm{C}^{19} \mathrm{H}_{3}-\mathrm{C}$ torsion; $\mathrm{C}^{3}-\mathrm{C}^{24}-\mathrm{C}^{26}$ deformation \\
\hline 267 & & $255(0 ; 0)$ & $250(0 ; 0)$ & $\mathrm{C}^{15} \mathrm{H}_{3}-\mathrm{C}, \mathrm{C}^{19} \mathrm{H}_{3}-\mathrm{C}$ torsions; $\mathrm{C}^{3}-\mathrm{C}^{24}-\mathrm{C}^{26}$ deformation \\
\hline 306 & & $299(1 ; 1)$ & $288(1 ; 2)$ & $\mathrm{C}^{11}-\mathrm{C}^{14}-\mathrm{C}^{15}, \mathrm{C}^{26}-\mathrm{C}^{24}-\mathrm{C}^{3}$ deformations \\
\hline \multicolumn{5}{|r|}{ ( } \\
\hline 327 & & $306(1 ; 1)$ & $319(1 ; 0)$ & $\mathrm{C}^{11}-\mathrm{C}^{14}-\mathrm{C}^{15}$ deformation \\
\hline 359 & & $353(2 ; 1)$ & $350(2 ; 1)$ & $C^{11}-C^{14}-C^{19}$ deformation; $C^{11}-\phi-C^{24}$ wagging (10b) \\
\hline 384 & & $379(1 ; 0)$ & $380(0 ; 0)$ & $\mathrm{C}^{11}-\phi-\mathrm{C}^{24}$ in-plane out-of-phase bending (9b) \\
\hline 413 & & $405(3 ; 3)$ & $409(3 ; 1)$ & $\mathrm{C}^{15}-\mathrm{C}^{14}-\mathrm{C}^{19}$ deformation \\
\hline 424 & 423 & $420(0 ; 0)$ & $\begin{array}{l}424(1 ; 1) \\
445(1 ; 7)\end{array}$ & $\begin{array}{l}\phi \text { out-of-plane bend (16a); } \mathrm{C}^{14}\left(\mathrm{C}^{11} \mathrm{C}^{15} \mathrm{C}^{19}\right) \text { sym. deform. } \\
\mathrm{C}^{24}-\mathrm{C}^{30} \text {-OH deformation; } \mathrm{C}^{14}\left(\mathrm{C}^{11} \mathrm{C}^{15} \mathrm{C}^{19}\right) \text { sym. deform. }\end{array}$ \\
\hline 477 & 480 & $472(1 ; 10)$ & & $\mathrm{C}^{24}-\mathrm{C}^{30}-\mathrm{OH}$ deformation; $\phi$ in-plane bending $(6 \mathrm{~b})$; \\
\hline \multirow[t]{3}{*}{523} & 522 & $512(1 ; 2)$ & & CO-H bending; $\phi$ out-of-plane bending (16b) \\
\hline & & & $554(1 ; 5)$ & CO-H bending; $\phi$ out-of-plane bending (16b) \\
\hline & & & $566(1 ; 28)$ & $\phi$ out-of-plane bending $(16 \mathrm{~b}) ; \mathrm{C}^{24}-\mathrm{C}^{30}-\mathrm{OH}$ deformation \\
\hline \multirow[t]{2}{*}{586} & 589 & $597(2 ; 35)$ & & $\phi$ out-of-plane bending (16b); $\mathrm{C}^{24}-\mathrm{C}^{30}-\mathrm{OH}$ deformation \\
\hline & & $605(3 ; 47)$ & $606(3 ; 38)$ & $\mathrm{CO}-\mathrm{H}$ out-of-plane bending; $\mathrm{C}^{24} \mathrm{C}^{30}=\mathrm{O}$ def.; $\mathrm{C}^{26} \mathrm{C}^{24} \mathrm{C}^{30}$ def. \\
\hline \multirow[t]{2}{*}{637} & 636 & & & \\
\hline & & $623(6 ; 30)$ & $626(6 ; 44)$ & CO-H out-of-plane bending; $\phi$ in-plane bending (6b) \\
\hline \multirow[t]{2}{*}{662} & 669 & & & \\
\hline & & $638(4 ; 13)$ & $640(4 ; 23)$ & $\mathrm{CO}-\mathrm{H}$ out-of-plane bend; $\mathrm{C}^{24} \mathrm{C}^{30}=\mathrm{O}$ def.; $\phi$ in-pl. bend $(6 \mathrm{~b})$ \\
\hline \multirow[t]{2}{*}{692} & 691 & $690(1 ; 51)$ & $694(1 ; 39)$ & C-OH stretch; $\mathrm{C}^{3}-\mathrm{C}^{24}$ stretch; $\phi$ out-of-plane bend (4) \\
\hline & & $726(9 ; 8)$ & $719(4 ; 16)$ & $\phi$ out-of-plane bending (4); $\mathrm{C}=\mathrm{O}$ out-of-plane wagging \\
\hline \multirow[t]{2}{*}{746} & 747 & & & \\
\hline & & $767(5 ; 16)$ & $776(21 ; 6)$ & $\mathrm{CH}_{3}$ rocking; $\phi \mathrm{CH}$ out-of-plane bending (17b) \\
\hline \multirow[t]{2}{*}{783} & 780 & & & \\
\hline & & $792(8 ; 11)$ & $787(1 ; 14)$ & $\phi$ out-of-plane bend (4); $\mathrm{CH}_{3}$ rock; $\mathrm{C}=\mathrm{O}$ out-of-plane wagg. \\
\hline 809 & 810 & & & \\
\hline \multirow[t]{2}{*}{820} & 820 & & & \\
\hline & & $808(16 ; 1)$ & $805(6 ; 1)$ & $\mathrm{C}^{26} \mathrm{H}_{3}$ rocking; $\mathrm{C}^{6}-\mathrm{C}^{11}$ stretch.; $\mathrm{C}^{14}\left(\mathrm{C}^{11} \mathrm{C}^{15} \mathrm{C}^{19}\right)$ sym. stretch. \\
\hline \multirow[t]{2}{*}{833} & 834 & & & \\
\hline & & $820(4 ; 4)$ & $824(7 ; 2)$ & $\phi \mathrm{CH}$ out-of-plane bending (10a) \\
\hline \multirow[t]{2}{*}{850} & 850 & & & \\
\hline & & $827(5 ; 2)$ & $827(7 ; 3)$ & $\phi \mathrm{CH}$ out-of-plane bending (10a); $\mathrm{C}^{26} \mathrm{H}_{3}$ rocking \\
\hline 865 & 867 & $839(2 ; 14)$ & $836(4 ; 17)$ & $\phi \mathrm{CH}$ out-of-plane bending $(17 \mathrm{~b}) ; \mathrm{CH}_{3}$ rocking \\
\hline \multirow[t]{2}{*}{880} & 880 & $866(4 ; 2)$ & $866(3 ; 2)$ & $\mathrm{CH}_{2}$ rocking; $\mathrm{C}^{19} \mathrm{H}_{3}$ rocking; $\mathrm{C}^{14} \mathrm{H}^{20}$ bending \\
\hline & & $922(2 ; 1)$ & $921(4 ; 1)$ & $\mathrm{H}^{9}-\mathrm{C}^{4} \mathrm{C}^{5}-\mathrm{H}^{10}$ out-of-phase bending; $\mathrm{C}^{15} \mathrm{H}_{3}$ rocking \\
\hline \multirow[t]{2}{*}{920} & $\sim 921$ & & & \\
\hline & 937 & $927(7 ; 0)$ & $928(5 ; 0)$ & $\begin{array}{l}\phi \mathrm{CH} \text { out-of-plane bend. }(17 \mathrm{a}) ; \mathrm{C}^{15} \mathrm{H}_{3} \text { rocking } \\
(\mathrm{CO}-\mathrm{H} \text { bending }(\mathrm{H}-\text { bonded }))\end{array}$ \\
\hline 943 & 945 & $937(5 ; 0)$ & $938(3 ; 0)$ & $\begin{array}{l}\mathrm{H}^{7}-\mathrm{C}^{1} \mathrm{C}^{2}-\mathrm{H}^{8} \text { out-of-phase bend; } \mathrm{C}^{15} \mathrm{H}_{3} \text { rock; } \mathrm{C}^{19} \mathrm{H}_{3} \text { rock } \\
\quad(\mathrm{CO}-\mathrm{H} \text { bending (H-bonded) }\end{array}$ \\
\hline 951 & & $941(2 ; 0)$ & $939(3 ; 0)$ & $\mathrm{H}^{7}-\mathrm{C}^{1} \mathrm{C}^{2}-\mathrm{H}^{8}$ out-of-phase bend; $\mathrm{C}^{15} \mathrm{H}_{3}$ rock; $\mathrm{C}^{19} \mathrm{H}_{3}$ rock \\
\hline 959 & 970 & $975(9 ; 3)$ & $975(8 ; 3)$ & $\mathrm{C}^{26} \mathrm{H}_{3}$ rocking; $\mathrm{C}^{26}-\mathrm{C}^{24}-\mathrm{C}^{30}$ antisymmetric stretching \\
\hline 1007 & 1008 & $1002(0 ; 5)$ & $1001(0 ; 5)$ & $\phi \mathrm{CH}$ in-plane bend. (18a) \\
\hline \multirow[t]{2}{*}{1021} & 1020 & & & \\
\hline & & $1050(2 ; 39)$ & $1051(2 ; 33)$ & $\mathrm{CH}_{2}$ twisting; $\mathrm{C}^{26} \mathrm{H}_{3}$ rocking; $\mathrm{C}^{24}-\mathrm{H}^{25}$ bend \\
\hline
\end{tabular}

(Continued) 
Table 3. (Continued)

\begin{tabular}{|c|c|c|c|c|}
\hline \multirow[b]{2}{*}{ Raman } & \multirow[b]{2}{*}{ FTIR } & \multicolumn{2}{|c|}{ Calculated $^{a}$} & \multirow[b]{2}{*}{ Approximate descriptions ${ }^{b}$} \\
\hline & & Conformer A & Conformer B & \\
\hline 1066 & 1068 & $1061(1 ; 16)$ & $1062(1 ; 7)$ & $\mathrm{CH}_{2}$ twisting; $\mathrm{C}^{26} \mathrm{H}_{3}$ rocking; $\mathrm{C}^{24}-\mathrm{H}^{25}$ bend \\
\hline 1074 & 1074 & $1072(3 ; 19)$ & $1072(3 ; 32)$ & $\mathrm{CH}_{2}$ twisting; $\mathrm{C}^{26} \mathrm{H}_{3}$ rocking; $\mathrm{C}^{19} \mathrm{H}_{3}$ rocking; $\mathrm{C}^{14}-\mathrm{H}^{20}$ bend \\
\hline 1093 & 1092 & $1101(12 ; 1)$ & $1101(9 ; 1)$ & $\mathrm{C}^{15} \mathrm{H}_{3}$ rocking; $\mathrm{C}^{14}\left(\mathrm{C}^{11} \mathrm{C}^{15} \mathrm{C}^{19}\right)$ antisymmetric stretching \\
\hline 1115 & $\sim 1116$ & $1113(1 ; 21)$ & $1113(4 ; 13)$ & $\phi \mathrm{CH}$ in-plane bending $(18 \mathrm{~b})$ \\
\hline \multirow[t]{2}{*}{$\sim 1124$} & 1123 & $1134(1 ; 215)$ & $1134(1 ; 208)$ & $\mathrm{C}-\mathrm{O}$ stretching; $(\mathrm{CO}-\mathrm{H}$ in-plane bend $)$ \\
\hline & & $1157(4 ; 10)$ & $1157(4 ; 12)$ & $\mathrm{C}^{15} \mathrm{H}_{3}$ rocking; $\mathrm{C}^{19} \mathrm{H}_{3}$ rocking; $\mathrm{C}^{11}-\mathrm{C}^{14}$ stretching \\
\hline \multirow[t]{2}{*}{$\sim 1168$} & 1168 & $1171(42 ; 16)$ & $1171(37 ; 13)$ & $\phi \mathrm{CH}$ in-plane bending $(9 \mathrm{a}) ; \mathrm{C}^{3}-\mathrm{C}^{24}$ stretching \\
\hline & & $1179(9 ; 10)$ & $1180(12 ; 9)$ & $\phi \mathrm{CH}$ in-plane bending $(9 \mathrm{a}) ; \mathrm{C}^{3}-\mathrm{C}^{24}$ stretching \\
\hline \multirow[t]{2}{*}{1181} & 1184 & & & \\
\hline & & $1189(13 ; 2)$ & $1188(14 ; 3)$ & $\mathrm{C}_{6}-\mathrm{C}_{11}$ stretching \\
\hline 1207 & 1208 & $1211(6 ; 1)$ & $1211(6 ; 2)$ & $\mathrm{CH}_{2}$ twisting \\
\hline \multirow[t]{2}{*}{1227} & 1231 & & & $\mathrm{CO}-\mathrm{H}$ in-plane bending (H-bonded) \\
\hline & & $1246(6 ; 5)$ & $1245(6 ; 5)$ & $\mathrm{C}^{24}-\mathrm{H}^{25}$ bend; (CO-H in-plane bending) \\
\hline 1267 & 1269 & $1274(7 ; 3)$ & $1273(9 ; 3)$ & $\mathrm{C}^{24}-\mathrm{H}^{25}$ bending; (CO-H in-plane bending) \\
\hline 1283 & $\sim 1283$ & $1278(20 ; 4)$ & $1281(16 ; 1)$ & $\mathrm{CH}_{2}$ wagging; $\mathrm{C}^{24}-\mathrm{H}^{25}$ bending \\
\hline 1305 & 1306 & $1308(3 ; 3)$ & $1308(2 ; 2)$ & $\phi$ in-plane bend (3); $\mathrm{CH}_{2}$ twisting; $\mathrm{C}^{14}-\mathrm{H}^{20}$ bending \\
\hline 1323 & 1321 & $1322(2 ; 0)$ & $1322(5 ; 0)$ & $\phi$ in-plane bend (3); $\mathrm{C}^{24}-\mathrm{H}^{25}$ bend $+\mathrm{CO}-\mathrm{H}$ in-plane bend \\
\hline$\sim 1332$ & 1330 & $1332(3 ; 1)$ & $1333(2 ; 1)$ & $\mathrm{C}^{14}-\mathrm{H}^{20}$ bending; $\mathrm{C}^{11}-\mathrm{H}^{12}$ bending \\
\hline 1340 & & $1336(32 ; 4)$ & $1339(32 ; 4)$ & $\mathrm{C}^{14}-\mathrm{H}^{20}$ bending; $\mathrm{C}^{11}-\mathrm{H}^{13}$ bending \\
\hline \multirow[t]{2}{*}{1366} & 1365 & $1361(3 ; 55)$ & $1361(3 ; 52)$ & $\mathrm{C}^{24}-\mathrm{H}^{25}$ bending; $\mathrm{C}^{24}-\mathrm{C}^{30}-\mathrm{O}^{32}$ stretching; (CO-H bending) \\
\hline & & $1375(6 ; 4)$ & $1374(6 ; 4)$ & $\mathrm{C}^{15} \mathrm{H}_{3}$ and $\mathrm{C}^{19} \mathrm{H}_{3}$ out-of-phase symmetric deformation \\
\hline \multirow[t]{2}{*}{1380} & 1380 & $1382(3 ; 7)$ & $1382(3 ; 6)$ & $\mathrm{C}^{26} \mathrm{H}_{3}$ symmetric deformation \\
\hline & & $1393(2 ; 4)$ & $1392(2 ; 5)$ & $\mathrm{C}^{15} \mathrm{H}_{3}$ and $\mathrm{C}^{19} \mathrm{H}_{3}$ in-phase symmetric deformation \\
\hline$\sim 1418$ & 1421 & $1413(0 ; 10)$ & $1413(6 ; 1)$ & $\phi \mathrm{C}-\mathrm{C}$ stretching (19b); $\mathrm{CH}_{2}$ twist; $\mathrm{C}^{3}-\mathrm{C}^{24}-\mathrm{H}^{25}$ deformation \\
\hline 1430 & 1421 & & & $\mathrm{CO}-\mathrm{H}$ bending (H-bonded) \\
\hline 1443 & 1443 & $1453(7 ; 1)$ & $1453(34 ; 1)$ & $\begin{array}{l}\mathrm{CH}_{2} \text { deformation; } \mathrm{C}^{15} \mathrm{H}_{3} \text { and } \mathrm{C}^{19} \mathrm{H}_{3} \text { antisymmetric } \\
\text { deformation }\end{array}$ \\
\hline \multirow[t]{3}{*}{1452} & 1452 & $1460(35 ; 1)$ & $1461(16 ; 4)$ & $\mathrm{C}^{15} \mathrm{H}_{3}$ and $\mathrm{C}^{19} \mathrm{H}_{3}$ antisymmetric deformation \\
\hline & & $1462(14 ; 4)$ & $1463(2 ; 3)$ & $\mathrm{C}^{26} \mathrm{H}_{3}$ antisymmetric deformation \\
\hline & & $1467(1 ; 2)$ & $1466(2 ; 3)$ & $\begin{array}{l}\mathrm{CH}_{2} \text { deformation; } \mathrm{C}^{15} \mathrm{H}_{3} \text { and } \mathrm{C}^{19} \mathrm{H}_{3} \text { antisymmetric } \\
\text { deformation }\end{array}$ \\
\hline \multirow[t]{3}{*}{1460} & 1462 & $1469(16 ; 8)$ & $1469(18 ; 7)$ & $\mathrm{C}^{26} \mathrm{H}_{3}$ antisymmetric deformation \\
\hline & & $1479(33 ; 3)$ & $1475(34 ; 3)$ & $\mathrm{C}^{15} \mathrm{H}_{3}$ and $\mathrm{C}^{19} \mathrm{H}_{3}$ in-phase antisymmetric deformation \\
\hline & & $1481(1 ; 9)$ & $1481(1 ; 9)$ & $\mathrm{C}^{15} \mathrm{H}_{3}$ and $\mathrm{C}^{19} \mathrm{H}_{3}$ in-phase antisymmetric deformation \\
\hline 1508 & 1508 & $1501(1 ; 22)$ & $1501(0 ; 22)$ & $\phi \mathrm{C}-\mathrm{C}$ stretching $(19 \mathrm{a}) ; \mathrm{C}^{3}-\mathrm{C}^{24}$ and $\mathrm{C}^{6}-\mathrm{C}^{11}$ stretching \\
\hline 1575 & & $1566(4 ; 0)$ & $1565(3 ; 0)$ & $\phi \mathrm{C}-\mathrm{C}$ stretching $(9 \mathrm{~b})$ \\
\hline 1608 & & $1606(100 ; 1)$ & $1606(100 ; 1)$ & $\phi \mathrm{C}-\mathrm{C}$ stretching $(9 \mathrm{a})$ \\
\hline \multirow[t]{2}{*}{1654} & & - & - & Overtone $\left(2 \times 833 \mathrm{~cm}^{-1}\right)$ \\
\hline & 1720 & $1765(6 ; 230)$ & $1764(6 ; 230)$ & $\mathrm{C}^{30}=\mathrm{O}^{31}$ stretching $(\mathrm{H}-$ bonded $)$ \\
\hline 2717 & & - & - & Combination mode \\
\hline 2737 & 2731 & - & - & Combination mode \\
\hline 2755 & & - & - & Combination mode \\
\hline 2787 & & - & - & Combination mode \\
\hline 2851 & 2851 & & & \\
\hline 2867 & 2869 & $2899(92 ; 7)$ & $2900(92 ; 6)$ & $\mathrm{C}^{14}-\mathrm{H}^{20}$ stretching \\
\hline 2874 & 2874 & $2911(35 ; 27)$ & $2911(36 ; 29)$ & $\mathrm{CH}_{2}$ symmetric stretching \\
\hline 2895 & & $2918(21 ; 36)$ & $2918(9 ; 30)$ & $\mathrm{C}^{15} \mathrm{H}_{3}$ and $\mathrm{C}^{19} \mathrm{H}_{3}$ out-of-phase symmetric stretchings \\
\hline \multirow[t]{2}{*}{2919} & 2923 & & & \\
\hline & & $2924(231 ; 37)$ & $2924(240 ; 42)$ & $\mathrm{C}^{15} \mathrm{H}_{3}$ and $\mathrm{C}^{19} \mathrm{H}_{3}$ in-phase symmetric stretchings \\
\hline
\end{tabular}

(Continued) 
Table 3. (Continued)

\begin{tabular}{|c|c|c|c|c|}
\hline \multirow[b]{2}{*}{ Raman } & \multirow[b]{2}{*}{ FTIR } & \multicolumn{2}{|c|}{ Calculated $^{a}$} & \multirow[b]{2}{*}{ Approximate descriptions ${ }^{b}$} \\
\hline & & Conformer A & Conformer B & \\
\hline 2941 & & $\begin{array}{l}2945(141 ; 26) \\
2949(28 ; 20)\end{array}$ & $\begin{array}{l}2944(145 ; 28) \\
2949(28 ; 21)\end{array}$ & $\begin{array}{l}\mathrm{C}^{26} \mathrm{H}_{3} \text { symmetric stretching } \\
\mathrm{CH}_{2} \text { antisymmetric stretching }\end{array}$ \\
\hline 2955 & 2956 & $2962(57 ; 10)$ & $2963(56 ; 10)$ & $\mathrm{C}^{24}-\mathrm{H}^{25}$ stretching \\
\hline$\sim 2965$ & $\sim 2965$ & $2978(17 ; 8)$ & $2978(17 ; 8)$ & $\mathrm{C}^{15} \mathrm{H}_{3}$ and $\mathrm{C}^{19} \mathrm{H}_{3}$ out-of-phase antisymmetric stretchings \\
\hline $\begin{array}{l}2992 \\
3003\end{array}$ & 2992 & $\begin{array}{c}2984(90 ; 58) \\
2989(116 ; 48) \\
3003(55 ; 37) \\
3010(104 ; 30)\end{array}$ & $\begin{array}{c}2984(97 ; 62) \\
2990(106 ; 44) \\
3003(60 ; 36) \\
3010(109 ; 29)\end{array}$ & $\begin{array}{l}\mathrm{C}^{15} \mathrm{H}_{3} \text { and } \mathrm{C}^{19} \mathrm{H}_{3} \text { in-phase antisymmetric stretchings } \\
\mathrm{C}^{15} \mathrm{H}_{3} \text { antisymmetric stretching } \\
\mathrm{C}^{19} \mathrm{H}_{3} \text { antisymmetric stretching } \\
\mathrm{C}^{26} \mathrm{H}_{3} \text { antisymmetric stretching }\end{array}$ \\
\hline 3021 & 3020 & $\begin{array}{l}3031(31 ; 14) \\
3048(50 ; 14)\end{array}$ & $\begin{array}{l}3030(32 ; 14) \\
3050(38 ; 16)\end{array}$ & $\begin{array}{l}\mathrm{C}^{26} \mathrm{H}_{3} \text { antisymmetric stretching } \\
\mathrm{H}^{9}-\mathrm{C}^{4} \mathrm{C}^{5}-\mathrm{H}^{10} \text { antisymmetric stretching }\end{array}$ \\
\hline 3047 & 3045 & $\begin{array}{l}3055(50 ; 16) \\
3065(119 ; 21)\end{array}$ & $\begin{array}{c}3052(67 ; 13) \\
3067(112 ; 23)\end{array}$ & $\begin{array}{l}\mathrm{H}^{7}-\mathrm{C}^{1} \mathrm{C}^{2}-\mathrm{H}^{8} \text { antisymmetric stretching } \\
\mathrm{H}^{9}-\mathrm{C}^{4} \mathrm{C}^{5}-\mathrm{H}^{10} \text { symmetric stretching }\end{array}$ \\
\hline $\begin{array}{l}3063 \\
3087\end{array}$ & & $3079(92 ; 5)$ & $3078(94 ; 5)$ & $\mathrm{H}^{7}-\mathrm{C}^{1} \mathrm{C}^{2}-\mathrm{H}^{8}$ symmetric stretching \\
\hline $\begin{array}{l}3146 \\
3215\end{array}$ & & $\begin{array}{c}- \\
- \\
3536(169 ; 47)\end{array}$ & $\begin{array}{c}- \\
- \\
3537(156 ; 46)\end{array}$ & $\begin{array}{l}\text { Overtone/combination mode } \\
\text { Overtone/combination mode } \\
\mathrm{O}^{32}-\mathrm{H}^{33} \text { stretching }\end{array}$ \\
\hline
\end{tabular}

\footnotetext{
${ }^{a}$ At the B3LYP/6-31G* level of calculation; wave numbers above $600 \mathrm{~cm}^{-1}$ scaled by a factor of 0.9614 ((Scott and Radom (40)); in parentheses: Raman scattering activities in $\AA \cdot \mathrm{u}^{-1}$ and infrared intensities in $\mathrm{km} \mathrm{mol}^{-1}$.

${ }^{b}$ The commonly used Wilson notation for descriptions of benzene derivatives normal vibrations (Wilson Jr. ${ }^{41}$ ); Varsányi $1974^{42}$ ) is presented inside parentheses.
}

the corresponding normal modes of vibration. This assignment was based both in the calculated wave numbers and intensities, despite the latter are recognizably much less accurate. It may be concluded that the experimental vibrational spectra confidently reflect the presence of specific intermolecular interactions involving the carboxylic group. In fact, the band at $1720 \mathrm{~cm}^{-1}$, assigned to the $\mathrm{C}^{30}=\mathrm{O}^{31}$ stretching, displays a downward shift relative to the calculated value for the isolated molecule (Tab. 3). A similar deviation to low wave numbers is suggested to occur for the $\mathrm{O}-\mathrm{H}$ stretching vibration, since this mode is not observed at the predicted $3536 \mathrm{~cm}^{-1}$ frequency, probably occurring as a broad band at about 2900 $3000 \mathrm{~cm}^{-1}$, overruled by the intense $\mathrm{C}-\mathrm{H}$ stretching features. The $\mathrm{CO}-\mathrm{H}$ bending modes, in turn, display clear upward shifts relative to the calculated values for isolated ibuprofen: the calculated modes at 1123,1246 , and $1361 \mathrm{~cm}^{-1}$ corresponding to the experimental 1231, 1322, and $1430 \mathrm{~cm}^{-1}$ frequencies, respectively (Tab. 3). Moreover, the 937 and $945 \mathrm{~cm}^{-1}$ features, for instance, display a particularly high intensity in FTIR (as opposed to Raman), thus being empirically ascribed to $\mathrm{CO}-\mathrm{H}$ bending modes. This spectral behavior is characteristic of hydrogen bond type interactions. These close-contacts, which occur through the $\mathrm{O}^{31}$ and $\mathrm{H}^{33}$ atoms within the ibuprofen molecule, are also responsible for the presence of ibuprofen dimeric entities in condensed phases. ${ }^{35}$

\section{CONCLUSIONS}

The present study reports a thorough conformational analysis of the ibuprofen molecule, by DFT based methods. Eight different energy minima were found, displaying an s-cis orientation of the carboxylic group. The s-trans arrangement was not considered, since it was previously verified, for the analogous molecules, to be significantly less stable than its s-cis counterpart.

It was found that the relative orientation of the substituents in the ibuprofen molecule, which can 
be considered as a para-substituted phenyl ring, hardly affects its conformational stability. These groups can be located below or above the ring plane, either to the same side or in opposite positions, leading to only four low energy sets of conformers: $\mathrm{AB}\left(\Delta E \approx 0 \mathrm{kJmol}^{-1}\right), \mathrm{CD}(\Delta E \approx 4.1$ $\left.\mathrm{kJmol}^{-1}\right)$, EF $\left(\Delta E \approx 5.2 \mathrm{kJmol}^{-1}\right)$, and $\mathrm{GH}$ $\left(\Delta E \approx 9.2 \mathrm{kJmol}^{-1}\right)$, with populations at room temperature of $75,14,9$, and $2 \%$, respectively (Tab. 1). When considering Gibbs populations, however, these change to $84 \%\left(\Delta G \approx 0 \mathrm{kJmol}^{-1}\right)$, $5 \%\left(\Delta G \approx 6.7 \mathrm{kJmol}^{-1}\right), 10 \%\left(\Delta G \approx 5.4 \mathrm{kJmol}^{-1}\right)$, and $1 \%\left(\Delta G \approx 11.8 \mathrm{kJmol}^{-1}\right)$, due to the inclusion of the entropy effect.

Despite the very small energy difference between the $\mathrm{A}$ and $\mathrm{B}$ conformations, the optical vibrational spectroscopy data reflects the sole presence of $\mathrm{A}$ in the solid phase, most probably on account of a better packing of this structure in the crystal. Furthermore, spectroscopic evidence of intermolecular hydrogen bonds between the carboxylic groups of adjacent ibuprofen molecules, leading to the formation of dimers (in the condensed phase) was also obtained. Disruption of these dimeric species may be one of the key factors for the understanding of the pharmacokinetics and drug release behavior of ibuprofen containing controlled release systems.

This kind of conformational analysis based on both spectroscopic and theoretical studies yields information of the utmost relevance for the elucidation of the SAR's ruling the pharmacological characteristics of substituted $\alpha$-arylpropionic acids, mainly when coupled to biochemical activity evaluation experiments.

\section{ACKNOWLEDGMENTS}

M.L. Vueba acknowledges a Ph.D. fellowship from Gabinete de Relações Internacionais da Ciência e do Ensino Superior (GRICES) and Fundação para Ciência e Tecnologia (FCT) (Portugal). The authors thank Prof. M.P.M. Marques (QuímicaFísica Molecular, University of Coimbra) for helpful discussions.

\section{REFERENCES}

1. Marot C, Chavatte P, Lesieur D. 2000. Comparative molecular field analysis of selective cyclooxygenase-
2 (COX-2) inhibitors. Quant Struct-Activ Relat 19:127-134.

2. Selinsky BS, Gupta K, Sharkey CT, Loll PJ. 2001. Structural analysis of NSAID binding by prostaglandin $\mathrm{H}_{2}$ synthase: Time-dependent and time-independent inhibitors elicit identical enzyme conformations. Biochemistry 40:51725180 .

3. Llorens O, Pérez JJ, Palomer A, Mauleon D. 2002. Differential binding mode of diverse cyclooxygenase inhibitors. J Mol Graph Model 20:359-371.

4. Smeyers YG, Cuéllare-Rodriguez S, Galvez-Ruano E, Arias-Pérez MS. 1985. Conformational analysis of some $\alpha$-phenylpropionic acids with anti-inflammatory activity. J Pharm Sci 74:47-49.

5. Villa M, Smeyers NJ, Senent M-L, Smeyers YG. 2001. An ab initio structural study of some derivatives of ibuprofen as possible anti-inflammatory agents. J Mol Struct (Theochem) 537:265269.

6. Villa M, Bounaim L, Smeyers N, Senent ML, Ezamarty A, Smeyers YG. 2004. An ab initio structural study of some substituted ibuprofen derivatives as possible anti-inflammatory agents. Int J Quant Chem 97:883-888.

7. Vergote GJ, Vervaet C, Remon JP, Haemers T, Verpoort F. 2002. Near-infrared FT-Raman spectroscopy as a rapid analytical tool for the determination of diltiazem hydrochloride in tablets. Eur J Pharm Sci 16:63-67.

8. Vergote GJ, De Beer TRM, Vervaet C, Remon JP, Baeyens WRG, Diericx N, Verpoort F. 2004. In-line monitoring of a pharmaceutical blending process using FT-Raman spectroscopy. Eur J Pharm Sci 21: 479-485.

9. De Beer TRM, Vergote GJ, Baeyens WRG, Remon JP, Vervaet C, Verpoort F. 2004. Development and validation of a direct, non-destructive quantitative method for medroxyprogestererone acetate in a pharmaceutical suspension using FT-Raman spectroscopy. Eur J Pharm Sci 23:355-362.

10. Mura P, Bettinetti GP, Manderioli A, Faucci MT, Bramanti G, Sorrenti M. 1998. Interactions of ketoprofen and ibuprofen with $\beta$-cyclodextrins in solution and in the solid state. Int J Pharm 166:189 203.

11. Budavari S, O’Neil MJ, Smith A, Heckelman PE. 1989. In: The merck index. 11th ed. Rahway, New Jersey: Merck \& Co. 776 p.

12. Geisslinger G, Stock KP, Bach GL, Loew D, Brune K. 1989. R(-)- and S(+)-ibuprofen. Agents Actions 27:455-457.

13. Davies NM. 1998. Clinical pharmacokinetic of ibuprofen: The first 30 years. Clin Pharmacokinet 34: 101-154.

14. Evans AM. 2001. Comparative pharmacology of $\mathrm{S}$ (+)- ibuprofen and (RS)-ibuprofen. Clin Rheumatol 20:S9-S14. 
15. Lin W, Hayakawa T, Yanaguimoto H, Kuzuba M, Obara T, Ding G, Cui F, Inotsume N. 2004. Pharmacokinetic interaction of ibuprofen enantiomers in rabbits. J Pharm Pharmacol 56:317321.

16. Leo E, Forni F, Bernabei MT. 2000. Surface drug removal ibuprofen-loaded PLA miscrospheres. Int J Pharm 196:1-9.

17. Sweetman SC (editor). 2004. Martindale: The complete drug reference. 34th ed. London: The Pharmaceutical Press.

18. Vueba ML, Batista de Carvalho LAE, Veiga F, Sousa JJ, Pina ME. 2005. Role of cellulose ether polymers on ibuprofen release from matrix tablets. Drug Dev Ind Pharm 31:653-665.

19. Vueba ML, Batista de Carvalho LAE, Veiga F, Sousa JJ, Pina ME. 2006. Influence of cellulose ether mixtures on ibuprofen release: MC25, HPC and HPMC K100 M. Pharm Dev Technol 11:213228.

20. Nerurkar J, Jun HW, Price JC, Park MO. 2005. Controlled-release matrix tablets of ibuprofen using cellulose ethers and carrageenans: Effect of formulation factors on dissolution rates. Eur $\mathrm{J}$ Pharm Biopharm 61:56-68.

21. Babazadeh M. 2006. Synthesis and study of controlled release of ibuprofen from the new acrylic type polymers. Int J Pharm 316:68-73.

22. Shankland N, Florence AJ, Cox PJ, Wilson CC, Shankland K. 1998. Conformational analysis of ibuprofen by crystallographic database searching and potential energy calculation. Int J Pharm 165: 107-116.

23. Frisch MJ. 2003. Gaussian 03W, Revision D.01. Gaussian, Inc., Pittsburgh PA.

24. Lee C, Yang W, Parr RG. 1988. Development of the Colle-Salvetti Correlation-energy formulation into a functional of the electron density. Phys Rev B37:785.

25. Miehlich B, Savin A, Stoll H, Preuss H. 1989. Results obtained with the correlation energy density functionals of Becke and Lee, Yang and Parr. Chem Phys Lett 157:200.

26. Becke A. 1988. Density-functional exchangeenergy approximation with correct asymptatic behavior. Phys Rev A38:3098.

27. Becke A. 1993. Density-functional thermochemistry.III. The role of exact exchange. J Chem Phys 98:5648.

28. Hariharan PC, Pople JA. 1973. The influence of polarization functions on molecular orbital hydrogenation energies. Theor Chim Acta 28:213.

29. Peng C, Ayala PY, Schlegel HB, Frisch MJ. 1996. Using redundant internal coordinates to optimize equilibrium geometries and transition states. J Comput Chem 17:49.
30. Reed AEL, Curtiss A, Weinhold F. 1988. Intermolecular interactions from a natural bond orbital, donor-acceptor viewpoint. Chem Rev 88:899-926.

31. Weinhold F, Landis CR. 2005. Valency and bonding. A natural bond orbital donor-acceptor perspective. Cambridge, UK: Cambridge University Press.

32. Fausto R, Batista de Carvalho LAE, Teixeira-Dias JJC, Ramos MN. 1989. S-cis and s-trans conformers of formic, thioformic and dithioformic acids. J Chem Soc Faraday Trans 2 85:1945-1962.

33. Batista de Carvalho LAE, Marques MPM, TeixeiraDias JJC. 1999. Oxygen-by-sulfur substitutions in glycine: Conformational and vibrational effects. J Chem Soc Perkin Trans 2:2507-2514.

34. Vueba ML, Pina ME, Veiga F, Sousa JJ, Batista de Carvalho LAE. 2006. Conformational study of ketoprofen by combined DFT calculations and Raman spectroscopy. Int J Pharm 307:56-65.

35. Shankland N, Chick C, Wilson CC, Florence AJ, Cox PJ. 1997. Refinenent of ibuprofen by singlecrystal pulsed neutron diffraction. Acta Cryst C53:951-954.

36. Siam K, Klimkowski VJ, Ewbank JD, Schäfer L, Van Alsenoy C. 1984. Ab Initio studies of structural features not easily amenable to experiment. 38 . Structural and conformational investigations of propanoic, 2-methylpropanoic, and butanoic acid. J Comput Chem 5:451-456.

37. Batista de Carvalho LAE, Teixeira-Dias JJC, Fausto R. 1990. The $\mathrm{CH} 3 \mathrm{CH} 2 \Pi$ internal rotation in thiopropionic acid as studied by ab initio SCFMO method. J Mol Struct (Theochem) 208:109121.

38. Teixeira-Dias JJC, Fausto R, Batista de Carvalho LAE. 1991. The $\mathrm{C} \alpha$-C internal rotation in $\alpha$-alkyl substituted carbonyls and thiocarbonyls: $\mathrm{CH}\left(\mathrm{CH}_{3}\right)_{2} \mathrm{C}(=\mathrm{X}) \mathrm{YH}(\mathrm{X}, \mathrm{Y}=\mathrm{O}$ or $\mathrm{S})$. J Comput Chem 12:1047-1057.

39. Benassi R, Taddei F. 1997. A theoretical approach to the factorization of the effects governing the barrier for internal rotation around $\mathrm{C}\left(\mathrm{sp}^{2}\right)-\mathrm{C}\left(\mathrm{sp}^{3}\right)$ bond into $\alpha$-substituted toluenes. J Mol Struct (Theochem) 418:59-71.

40. Scott AP, Radom L. 1996. Harmonic Vibrational Frequencies: An Evaluation of Hartree-Fock, Møller-Plesset, Quadratic Configuration Interaction, Density Functional Theory, and Semiempirical Scale Factors. J Phys Chem 100:1650216513.

41. Wilson EB Jr. 1934. The normal modes and frequencies of vibration of regular plane hexagon model of benzene molecule. Phys Rev 45:706-714.

42. Varsányi G. 1974. Assignments for vibrational spectra of seven hundred benzene derivatives. London: Adam Hilger Ltd.; Budapest: Akdémiai Kiadó. 